\title{
Stabilization of Clayey Silt Soil Using Small Amounts of Petrit T
}

\author{
Wathiq Al-Jabban ${ }^{1,2}$, Sven Knutsson' ${ }^{1}$, Jan Laue ${ }^{1}$, Nadhir Al-Ansari ${ }^{1}$ \\ ${ }^{1}$ Civil, Environmental and Natural Resources Engineering, Lulea University of Technology, Lulea, Sweden \\ ${ }^{2}$ Civil Engineering Dept., Collage of Engineer, University of Babylon, Babylon, Iraq \\ Email:wathiq.al-jabban@ltu.se,Sven.Knutsson@ltu.se,jan.laue@ltu.se,nadhir.alansari@ltu.se
}

How to cite this paper: Al-Jabban, W., Knutsson, S., Laue, J. and Al-Ansari, N. (2017) Stabilization of Clayey Silt Soil Using Small Amounts of Petrit T. Engineering, 9, 540-562.

https://doi.org/10.4236/eng.2017.96034

Received: June 9, 2017

Accepted: June 25, 2017

Published: June 28, 2017*

Copyright (c) 2017 by authors and Scientific Research Publishing Inc. This work is licensed under the Creative Commons Attribution International License (CC BY 4.0).

http://creativecommons.org/licenses/by/4.0/

\section{Open Access}

\begin{abstract}
Effects of using small amounts of a Petrit T, a by-product of manufacture sponge iron, to modify clayey silt soil were investigated in this study. Petrit $\mathrm{T}$ was added at $2 \%, 4 \%$ and $7 \%$ of soil dry weight. A series of unconfined compressive strength tests, consistency limits tests and $\mathrm{pH}$ tests were conducted at $7,14,28,60$ and 90 days of curing periods to evaluate the physical and mechanical properties of treated soil. Results indicated improving in the unconfined compressive strength, stiffness and workability of treated soil directly after treatment and over time. Increasing in soil density and decreasing in water content were observed, with increasing Petrit $\mathrm{T}$ content and curing time. The $\mathrm{pH}$ value was immediately increasing after treatment and then gradually decreased over time. Failure mode gradually changed from plastic to brittle behavior with increasing binder content and curing time. The outcomes of this research show a promising way of using a new by-product binder to stabilize soft soils in various engineering projects in order to reduce the costs which are associated with of excavation and transportation works.
\end{abstract}

\section{Keywords}

Stabilization, Petrit T, Industrial By-Product, Secant Modulus, Workability, Solidification, $\mathrm{pH}$ Value

\section{Introduction}

Chemical stabilization is a widely used, low-cost and effective technique to improve the physical and mechanical properties for a broad range of soils [1]. Numerous additives can be used to improve soft soils. Some of these additives are well known and commonly used, including cement and lime. In addition to by-products from industrial processes, such as various slags, fly ashes, and blast furnace slags are also used. 
In recent years, the benefits of using industrial by-product material for the purposes of soil stabilization have increased internationally as the binder material is considered to be cheap and easily available [2] [3] [4]. Moreover, it contributes to a decrease in the environmental impact posed by the production of these materials [5] [6] [7].

Extensive studies have been conducted on using industrial by-product materials for soil stabilization in a wide range of soils treated with high binder content $(>7 \%$ of soil dry weight). Enhancing soil strength and making the treated soil stronger and stiffer represent the most beneficial outcomes [6] [8]-[15]. However, in most of the reported studies, high binder amounts were used.

In contrast, benefits of using by-products materials such as fly ashes in smaller amounts (less than 7\%) have been recently investigated to improve the strength, stiffness and workability, in addition to decreasing costs and the environmental impact of stabilized soils [16] [17]. Therefore, there is a need to investigate the effectiveness of adding smaller amounts of by-product material (e.g., less than 7\%) to modify and improve the clayey silt soil.

Petrit $\mathrm{T}$ is a by-product of manufacturing of sponge iron. The material used here is produced by Höganäs, Sweden AB. The total yearly production of Petrit $\mathrm{T}$ of this plant ranges between 17,000 and 20,000 tones. It is primarily produced during the production process of sponge iron, when coke, limestone and anthracite are blended together into a reduction mix. During the production process, when the temperature reaches approximately $1200^{\circ} \mathrm{C}$, the carbon in the reduction mix reacts with the oxygen in the fine grounded iron ore. The fine ground iron ore is reduced, and forms sponge iron and, at the same time, the material sinters into pieces with a spongy structure. The remainder of the reduction mix forms a lime rich residual product called TK lime, which after some further processing (screening, etc.), becomes Petrit T [18].

This paper aims to study the effects of adding a small amount of Petrit $\mathrm{T}$ on the improvement of physical and mechanical properties of treated soil through an extensive experimental program which includes tests of Atterberg limits, unconfined compressive strength, and $\mathrm{pH}$ value at various amounts of Petrit $\mathrm{T}$ and curing time.

\section{Experimental Program}

A series of unconfined compression tests (UCS) were conducted on both untreated and treated soil at different Petrit $\mathrm{T}$ content and curing time, in addition to consistency limits, and the level of $\mathrm{pH}$ were determined after each stage. Improvement in soil strength was investigated by using unconfined compression tests (UCS). Enhancing in soil workability directly after treatment and over time was investigated by conducting Atterberg limits tests, to measure the reduction in the plasticity index.

Indication about soil-binder reactions progress was investigated by conducting $\mathrm{pH}$ test directly after treatment and over time.

The solidification is a term refers to the reduction in soil water content due to 
adding Petrit T directly after treatment and over time.

In addition, the stress-strain curves, soil density, failure strain, deformation modulus $\left(\mathrm{E}_{50}\right)$ and the ratio between $\mathrm{E}_{50}$ and UCS of the treated soil were measured and evaluated with different Pertit $\mathrm{T}$ contents and curing times. Main laboratory tests program is summarized in Table 1 .

\subsection{Soil}

The soil used in this study was originated from Gothenburg, Sweden. Untreated soil was investigated by series of laboratory tests, which includes particle size distribution, Atterberg limits, loss of ignition, chemical composition, compaction characteristics, $\mathrm{pH}$ value and specific density. Table 2 presents the basic physical and engineering properties and the major chemical composition of the untreated soil is listed in Table 3. The particle size distribution (PSD) of the untreated soil is shown in Figure 1. From PSD, the untreated soil mainly consists of silt (55\%), fine sand (29\%) and clay (16\%). The soil is classified as lean clay (CL) according to the Unified Classification System ASTM D 2487 [19], and as clayey silt soil ( $\mathrm{Cl} \mathrm{Si}$ ) according to the Swedish standard [20]. Organic content, assessed by loss of ignition test according to ASTM D2974 [21], was 4\%, and thus the untreated soil was classified as having a low organic content [22] [23].

\subsection{Binder (Petrit T)}

Höganäs Sweden AB provided the binder (Petrit $T$ ) used in this study. The chemical and physical properties of this particular Petrit T are listed in Table 3.

Table 1. Summary of main tests, curing time, binder contnet, compaction method and number of samples.

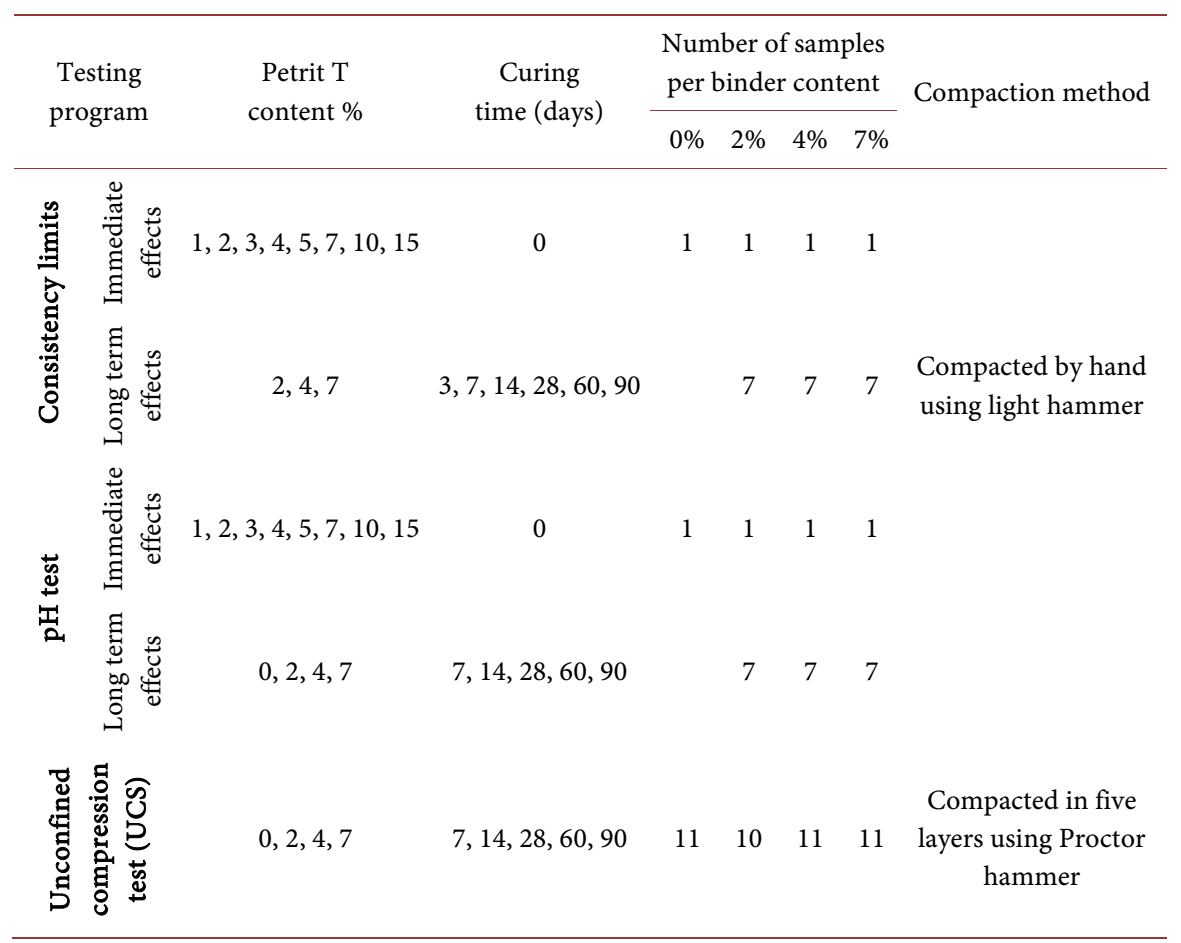


Table 2. Engineering properties of tested soils.

\begin{tabular}{cc}
\hline Parameters & Values \\
\hline Particle-size distribution (\%) & 29 \\
Sand (\%) $(1-0.63 \mathrm{~mm})$ & 55 \\
Silt (\%) $(0.063-0.002 \mathrm{~mm})$ & 16 \\
Clay (\%) $(<0.002 \mathrm{~mm})$ & \\
Consistency limits (\%) & 37 \\
Liquid limit (\%) & 20 \\
Plastic limit (\%) & 18 \\
Plasticity index (\%) & \\
Proctor test & 12 \\
Optimum moisture content $(\%)$ & 1.97 \\
Maximum dry density, $\mathrm{t} / \mathrm{m}^{3}$ & 30 \\
Natural water content $(\%)$ & 2.69 \\
Specific gravity Gs & 4 \\
\hline Loss of ignition $\%$ & \\
\hline
\end{tabular}

${ }^{*}$ Determined by the fall cone test.

Table 3. Chemical and physical properties of untreated soil and Petrit T binder.

\begin{tabular}{|c|c|c|}
\hline Parameter & Soil & $($ Petrit T) $[18]$ \\
\hline \multicolumn{3}{|l|}{ Chemical properties } \\
\hline Silicon oxide $\left(\mathrm{SiO}_{2}\right) \%$ & 65.7 & 19.7 \\
\hline Aluminum oxide $\left(\mathrm{Al}_{2} \mathrm{O}_{3}\right) \%$ & 12.3 & 9.8 \\
\hline Iron oxide $\left(\mathrm{Fe}_{2} \mathrm{O}_{3}\right)$ & 3.42 & 6.1 \\
\hline Sulfur trioxide $\left(\mathrm{SO}_{3}\right) \%$ & & 3.75 \\
\hline Magnesium oxide $(\mathrm{MgO}) \%$ & 1.31 & 1.14 \\
\hline Calcium oxide $(\mathrm{CaO}) \%$ & 2.4 & 36.8 \\
\hline Potassium oxide $\left(\mathrm{K}_{2} \mathrm{O}\right) \%$ & 2.84 & 0.63 \\
\hline Sodium oxide $\left(\mathrm{Na}_{2} \mathrm{O}\right) \%$ & 2.81 & 0.23 \\
\hline $\mathrm{MnO} \%$ & 0.0556 & 0.19 \\
\hline $\mathrm{P}_{2} \mathrm{O}_{5} \%$ & 0.159 & 0.31 \\
\hline $\mathrm{TiO}_{2} \%$ & 0.550 & 1.45 \\
\hline Cementing potential ratio $\left(\mathrm{CaO} / \mathrm{SiO}_{2}\right)$ & & 1.9 \\
\hline \multicolumn{3}{|l|}{ Physical properties } \\
\hline Loss of ignition \% & 4 & 18 \\
\hline Moisture content $\%$ & & 0 \\
\hline $\mathrm{pH}$ value & 5 & 12.85 \\
\hline \multicolumn{3}{|l|}{ Fineness } \\
\hline$<500 \mu \mathrm{m}(\%)$ & & 97.3 \\
\hline$<300 \mu \mathrm{m}(\%)$ & & 93.4 \\
\hline$<212 \mu \mathrm{m}(\%)$ & & 83.9 \\
\hline$<106 \mu \mathrm{m}(\%)$ & & 59.4 \\
\hline Retained on $45 \mu \mathrm{m}(\%)$ & & 40.3 \\
\hline
\end{tabular}




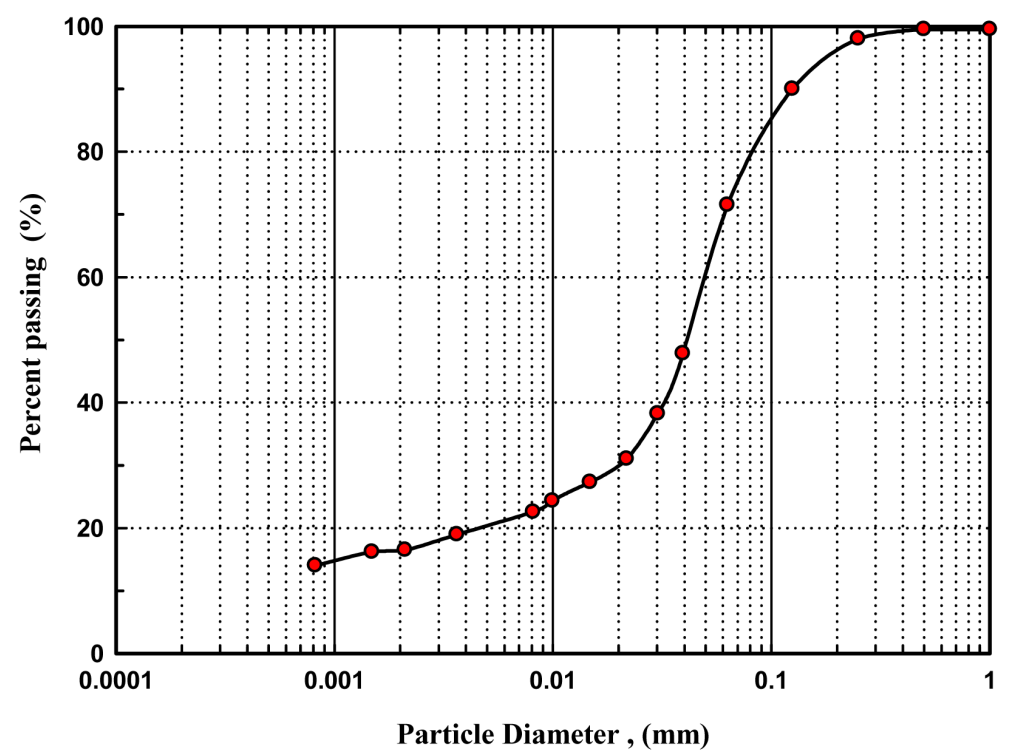

Figure 1. Particle size distribution of the untreated soil.

The cementing potential ratio (self-cementing properties) is expressed as a $\mathrm{CaO} / \mathrm{SiO}_{2}$ ratio [24]. Petrit $\mathrm{T}$ has a $\mathrm{CaO} / \mathrm{SiO}_{2}$ ratio of approximately 1.9 , compared to a Portland cement figure of approximately 3. The loss of ignition is $18 \%$, which represent the unburned carbon in the binder. In addition, an $\mathrm{x}$-ray diffraction (XRD) test indicates that the main chemical components of Petrit $\mathrm{T}$ binder consisted of $57 \%$ Larnite (dicalcium silicate), 28.3\% Gehlenite (calcium-silicon-aluminate), $11.5 \%$ quartz (silicon dioxide), and 3\% Portlandite (calcium hydroxide) [18].

Based on this, Petrit $\mathrm{T}$ binder has self-cementing properties in addition to having high amounts of dicalcium silicate. This is similar to the clinker mineral $\mathrm{C}_{2} \mathrm{~S}$ (belite) in Portland cement that is responsible for increased strength of cement over a relatively long curing period due to the lower reactivity.

\section{Samples Preparation and Testing Methodology}

Unconfined compressive samples (UCS) were prepared after crumbling the untreated soil with its initial water content (30\%), then Petrit $\mathrm{T}$ was added as a dried material at ratios of $2 \%, 4 \%$ and $7 \%$ by soil dry mass and mixing for ten minutes using a laboratory mixing machine. The soil-binder mixtures were gradually filled as layers by hand into cylindrical polyvinyl chloride (PVC) tubes $(170 \times 50 \mathrm{~mm}$, wall thickness $=1.9 \mathrm{~mm})$. Using a Proctor hammer, UCS samples was compacted in five layers, with 25 blows per layer which provides energy per volume $\left(600 \mathrm{~kJ} / \mathrm{m}^{3}\right)$. The total sample height was $100 \mathrm{~mm}$. The sample tubes were covered with a plastic cover and sealed with rubber lids at both ends to prevent access of water. The curing time was set at 7, 14, 28, 60 and 90 days before testing. For curing, the samples were placed inside a glass container partially filled with water as shows in Figure 2 to ensure 100\% of humidity and stored at a controlled room temperature of $20^{\circ} \mathrm{C}$. After curing, the samples were removed from the tubes by using a mechanical jack and subjected to the unconfined 


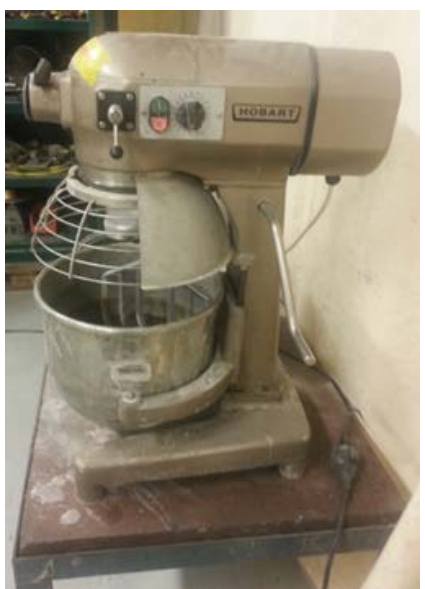

Laboratory mixer

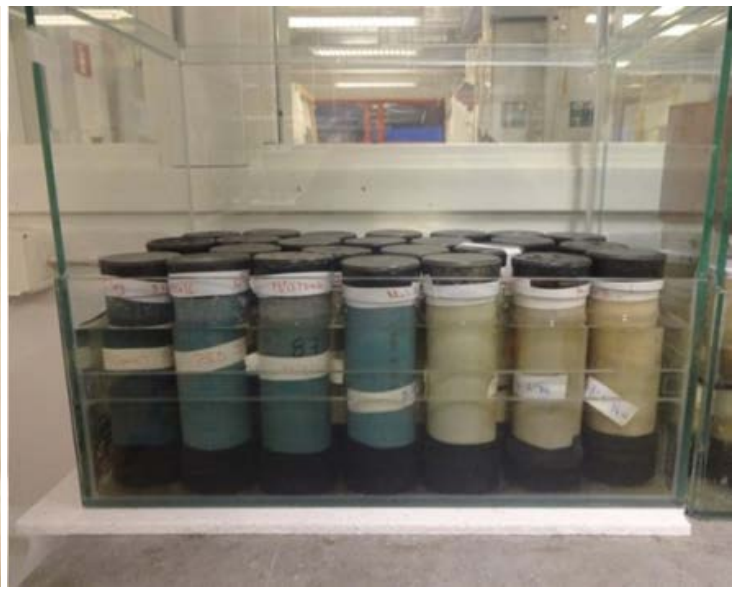

Curing container for UCS samples

Figure 2. Laboratory mixer and curing specimens prepared for UCS and consistency limits tests.

compression tests (UCS). The testing rate was $1 \mathrm{~mm} /$ minute until failure occurred. The height-to-diameter ratio of the UCS sample was 2 . Before testing, the sample was cut and smoothed to obtain parallel end surfaces. The end plates were lubricated with Vaseline to reduce friction. Water content and densities were determined in relation to the unconfined compression tests. All UCS samples were prepared during one hour after adding Petrit $\mathrm{T}$.

Atterberg limit samples were prepared and cured in a similar way to the unconfined compression samples, but using a light hammer for compaction, instead of a Proctor hammer, to remove air bubbles. After curing, the sample was removed from its tube and conducted to Liquid limit and plastic limit tests according to Swedish standards SS 0271201990 and SS 0271211990 [25] [26]. The liquid limit was found by using fall cone method. The liquid limit is representing the average of four determinations, while the mean of five tests represents the value of the plastic limit.

The $\mathrm{pH}$ tests were carried out using a HI $208 \mathrm{pH}$ meter which posses a magnetic stirrer for treated and untreated soils as per ASTM D4972 [27]. pH tests were performed by air drying and grinding material from the UCS samples. The average of three $\mathrm{pH}$ tests represents the soil $\mathrm{pH}$ value. The ratio of liquid to solid of 1 was used to mix the soil and distilled water. The mixture was poured into a glass container and mixed thoroughly by using a magnetic stirrer for 2 minutes. The mixture was left for one hour for retention and mixing process was continued repeated for every 10 minutes. The $\mathrm{pH}$ value was measured by inserting $\mathrm{pH}$ meter into the slurry.

\section{Results and Discussion}

Workable soil is defined as the soil which can be easily controlled and compacted homogenous. Increaser the workability of the treated is one of the main aims of the chemical treatment which lead to accelerate the construction work [28]. Decreasing the plasticity index has been shown to enhance the workability 
of the soil [29] [30] [31]. The immediate effect (after one hour) of mixing Petrit $\mathrm{T}$ on the Atterberg limits of the treated soil is shown in Figure 3. Addition of a small amount of Petrit $\mathrm{T}$ ( $1 \%$ to $5 \%$ ) has effects on increase both of the liquid limit (LL) and plastic limit (PL). Then, with further increase in Petrit T content to $5 \%$ and $7 \%$, the liquid limit remains almost constant, followed by slightly decreases at even higher content of binder (10\% and 15\%).

The plastic limit slightly increases due to addition in Petrit T from 5\% to $15 \%$ compared to the large increase at lower binder contents. Due to different trend behavior between LL and PL, the plasticity index (PI) slightly increased at small binder content $(1 \%-4 \%)$ and then followed by decrease as the binder content increase.

The immediate increase in the liquid limit after treatment was due to hydration reaction of binder which led to flocculate and agglomerate of soil particles during short period.

Previous studies of soil lime reaction, [32] found similar trends for lime treated black cotton clay with low clay content (19\%).This was explained by a low cation exchange capacity, leading to larger double layer. [33] also indicated similar trends of an increase in liquid and plastic limits at low lime content (1\% 3\%) for stabilized kaolinite with lime. [34] pointed out increases in liquid and plastic limits of Swedish soft clays after stabilization with different cementitious, lime and fly ashes. [16] [35] also reported similar trends by an increased fly ash. [36] [37] indicate that the presence of entrapped water within the intra-aggregate pores after flocculation and agglomeration has a dominant effect leading to immediate rise in liquid limit. In contrast, decreasing in liquid limit was observed with increase in binder content. A similar trend in the immediate change in the plasticity index is also consistent with previous studies for lime and fly ash treated soil [12] [33] [38] [39]. Thus, due to flocculation and agglomeration of soil particles after treatment with Petrit $\mathrm{T}$, treated soil showing

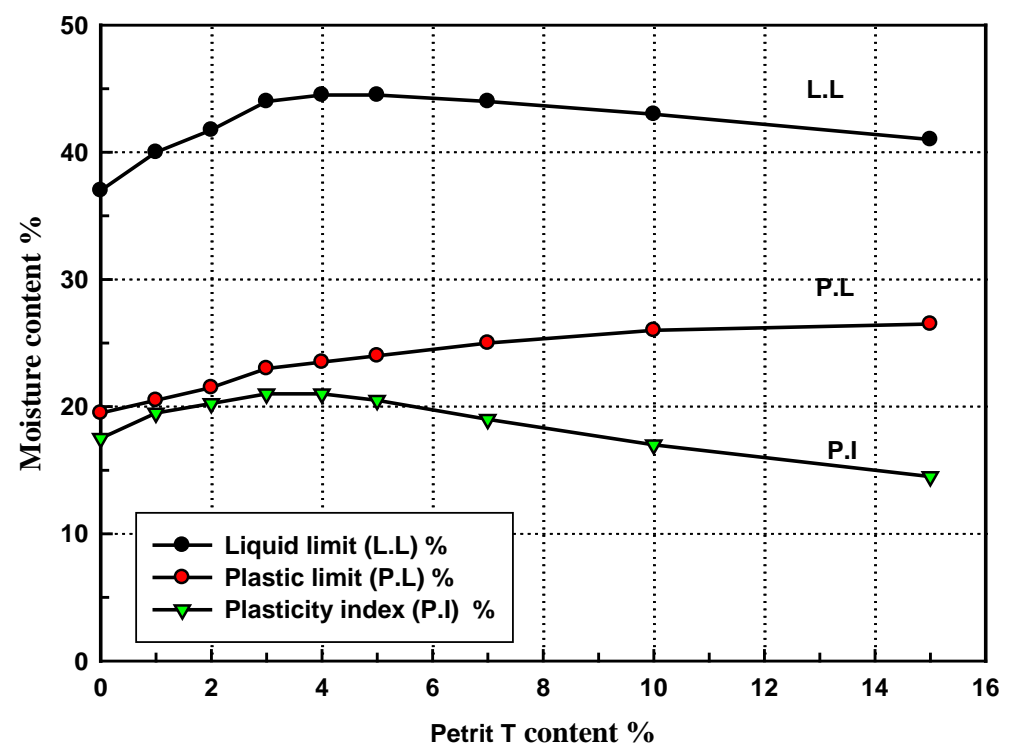

Figure 3. Immediate change in consistency limits versus Petrit T content. 
better workability with an increasing Petrite $\mathrm{T}$ content during a short time (one hour).

The effects of curing time on plasticity index of the treated soil are presents in Figure 4 . It can be seen that the plasticity index decreased with time, the decrease became larger with higher binder content. The decrease in the plastic index is due to decreases in liquid limits and an increase in plastic limits of the treated soil with time. A similar trend of decreasing plasticity index over time is consistent with [13] [34] [37] [40]. Thus, a continuous improvement in soil workability was achieved after a relatively long curing period after treatment.

\subsection{Water Content and Density}

Solidification is a term refers to the reduction in the water content of treated soil due to hydration reaction of binder [41].

The water content reduces immediately (one hour) after mixing Petrit $\mathrm{T}$ with untreated soil from its initial value, as shown in Figure 5. The hydration reaction between the Petrit $\mathrm{T}$ and water is the main reason for the reduction in water content (solidification). Solidification increases significantly with an increase in Petrit $\mathrm{T}$ content. A similar trend of rapid decrease in soil moisture content is consistent with [31] [42] for cement treated soil and [31] [43] [44] for soil treated with self-cementing fly ash.

Figure 6 shows the long term effect on the water content of treated soil. Figure 6 shows further decreases in water content is observed with increasing curing time. After 90 days of curing time, the reduction in water content is about $0.5 \%, 1 \%$ and $1.3 \%$ for $2 \%, 4 \%$ and $7 \%$ binder content respectively. This reduction in water content is mainly related to the hydration and pozzolanic reactions as the specimens were cured in a sealed condition. A similar trend of decrease in soil water content over time is also found by [45] for Bangkok soft clay treated with cement and fly ash.

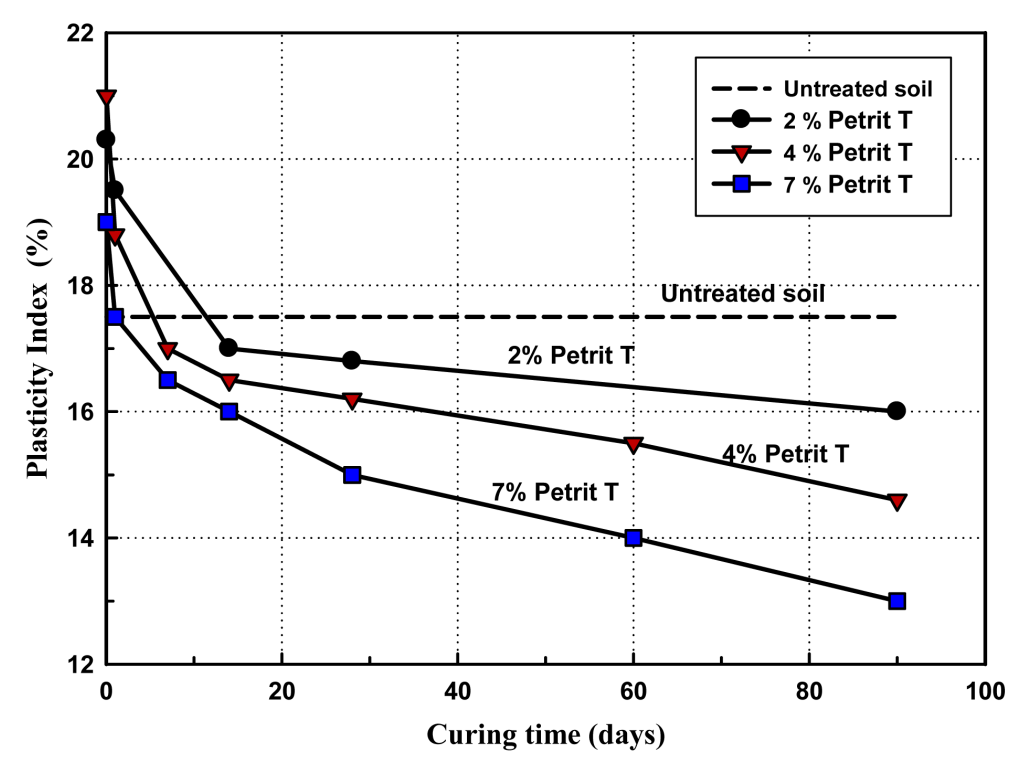

Figure 4. Effect of curing time and Petrit T content on plasticity index. 


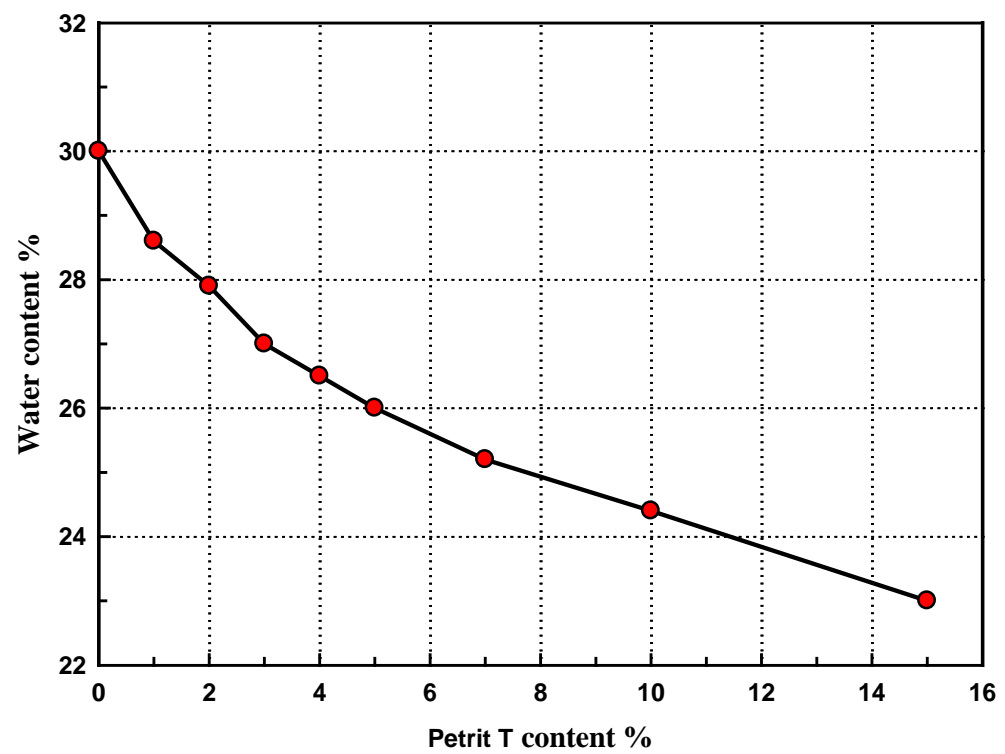

Figure 5. Immediate reduction in water content versus Petrit $\mathrm{T}$ content.

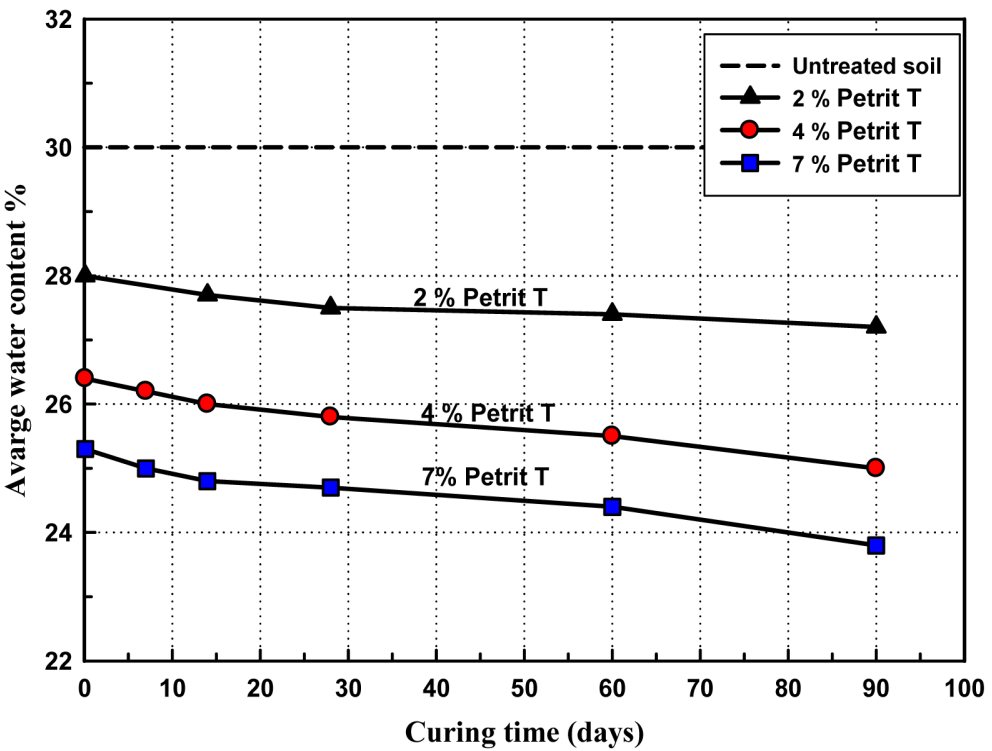

Figure 6. Effect of curing time and Petrit T content on water content.

From Figures 3-6, it is observed that the reduction in water content is accompanied by increase in the plastic limit. The relationship between water content and consistency limits due to the addition of Petrit $\mathrm{T}$ is explained by the liquidity index (LI), Equation (1). The relationship between liquidity index (LI) and Petrit T content after one hour of treatment is shown in Figure 7. It can be seen that, with the addition of various amounts of Petrit $\mathrm{T}$, the liquidity index (LI) is reduced from 0.6 (untreated soil) until it reaches the plastic limit $(\mathrm{LI}=0)$ at $7 \%$ binder content. The liquidity index is continuously decreased (below the plastic limit) as the binder content is increased above $7 \%$.

$$
\mathrm{LI}=\frac{\left(\mathrm{W}_{\mathrm{c}}-\mathrm{PL}\right)}{\mathrm{PI}}
$$


where: LI: liquidity index, $\mathrm{W}_{c}$ : water content, PL: Plastic limit and PI: Plasticity index.

The effect of curing time on the relationship between decrease in water content and the liquidity index is presented in Figure 8. As curing time increase, the liquidity index is further decreased with the decrease in water content. For $7 \%$ binder content, the liquidity index is lower than zero at a longer curing period, i.e. the water content is lower than the plastic limit. [34] has pointed out that the reduction in water content for the natural soil from around the liquid limit towards the plastic limit is accompanied by an increase in soil strength, which will be discussed later in this study.

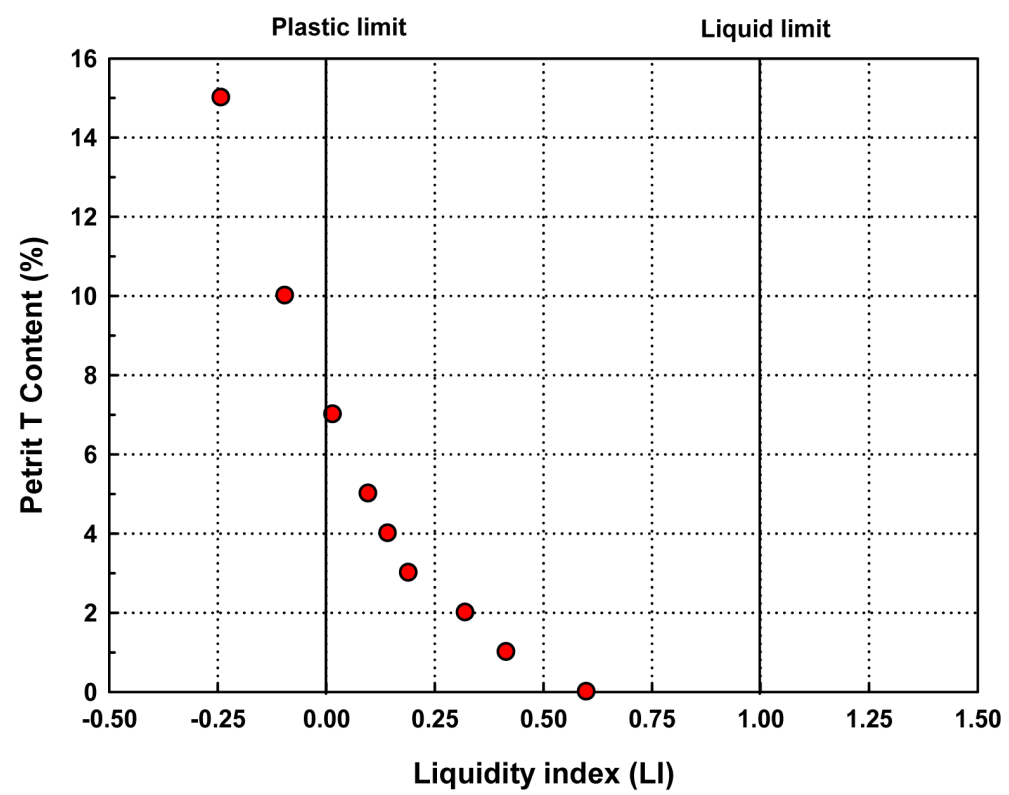

Figure 7. Liquidity index versus Petrit T content.

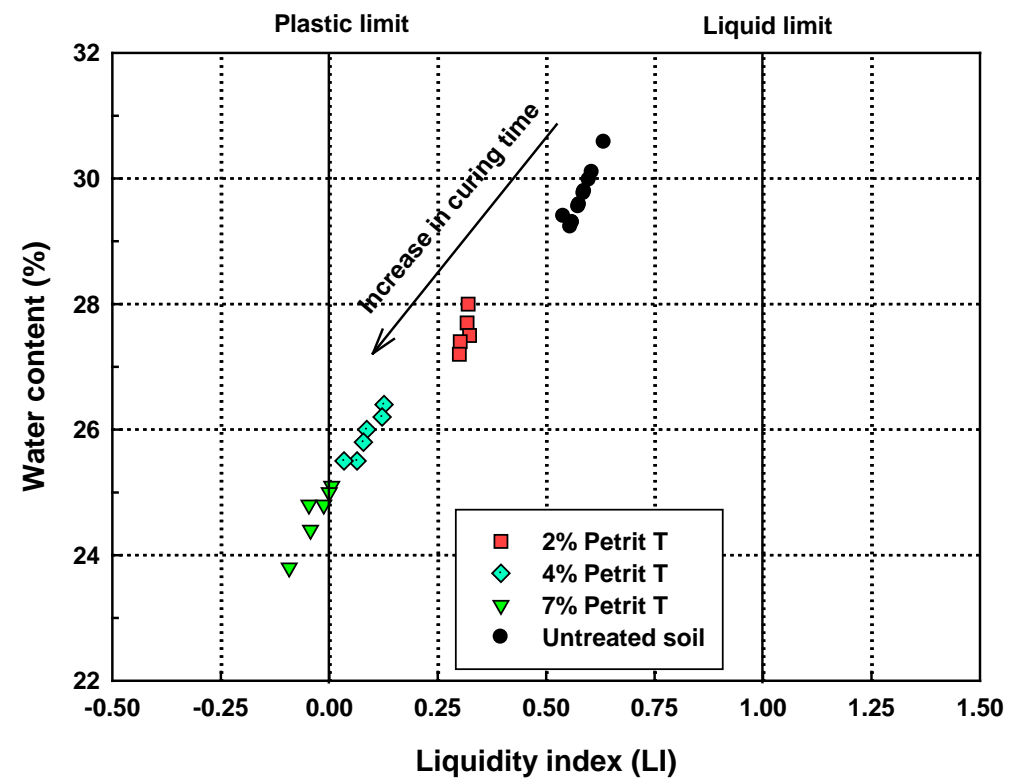

Figure 8. Liquidity index versus water content for all curing times. 
The effect of Petrit T content and curing time on the soil density is shown in Figure 9. The soil density increases with increasing Petrit $\mathrm{T}$ content and curing period (Figure 9). An increase in density is related to the deposition of CSH (calcium-silicate hydrate) and CAH (calcium-aluminate hydrate) gels, which are produced during the hydration and pozzolanic reactions and fill the pore voids.

In the hydration and pozzolanic reactions of the Petrit $\mathrm{T}$ binder, water is consumed, and large quantities of solid particles are introduced into the soil leading to an increase in density. Figure 10 shows that the density ranged between 1.92 $\mathrm{g} / \mathrm{cm}^{3}$ for untreated soil to $2.01 \mathrm{~g} / \mathrm{cm}^{3}$ for treated soil with $7 \%$ Petrit T. The reductions in soil water content were in the range of $2 \%$ to $6 \%$ for all samples. Similar observations of increased density and reduced water content for various binders have been reported by [34] [37] [46] [47] [48].

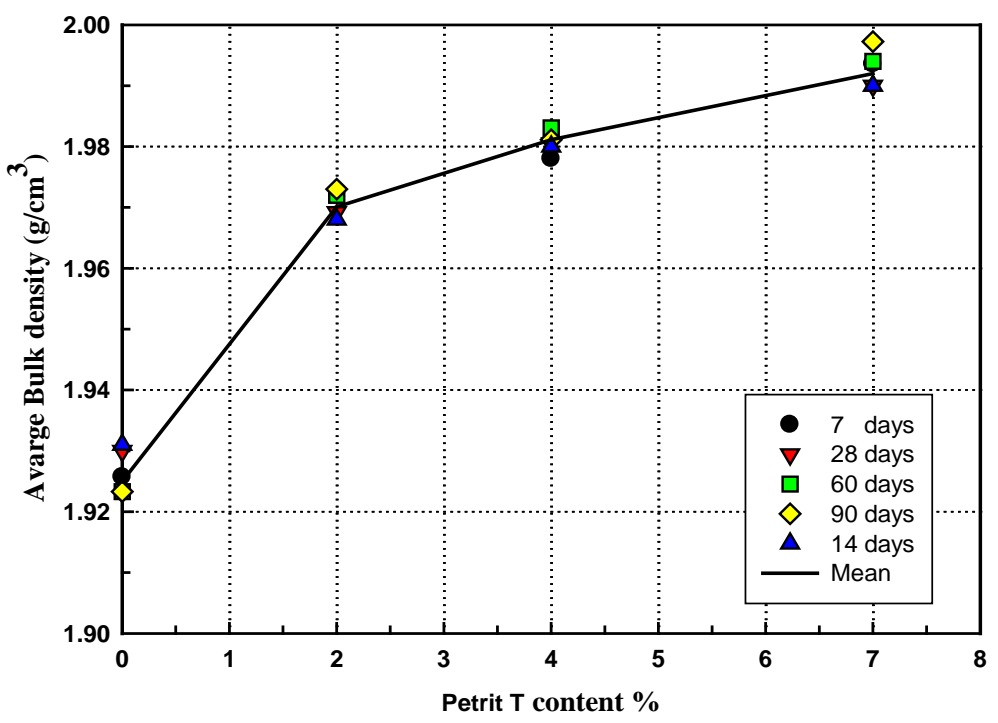

Figure 9. Avarge specimen density versus Petrit T content.

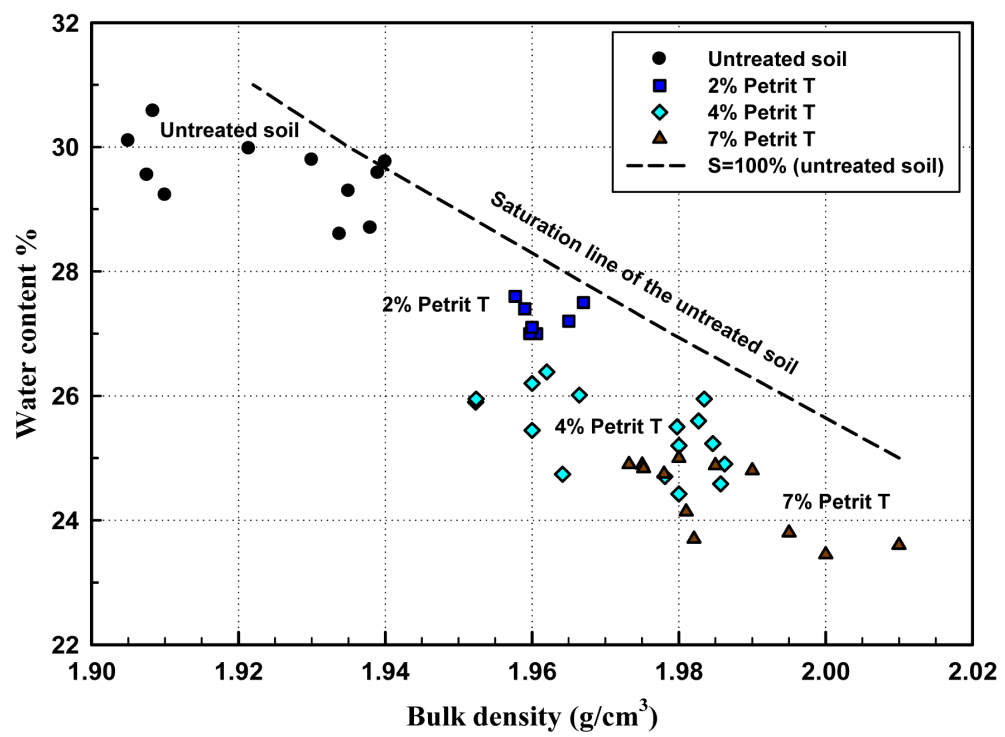

Figure 10. Specimen water content versus bulk density and Petrit T content for all curing time. 


\section{2. pH Value}

The immediate effect (after one hour) of mixing Petrit $\mathrm{T}$ on the soil $\mathrm{pH}$ value is presented in Figure 11. The $\mathrm{pH}$ value of treated soil rose from 5 to 12.3 as the Petrit $\mathrm{T}$ content was increased up to $7 \%$. Beyond that, the $\mathrm{pH}$ slightly increased to 13 at $15 \%$ Petrit $\mathrm{T}$ content. The reaction of Petrit $\mathrm{T}$ with water leads to the release of calcium ions $\left(\mathrm{Ca}^{2+}\right)$ increasing the $\mathrm{pH}$ value [37] [49].

Figure 12 shows the effect of curing time on the $\mathrm{pH}$ value of treated soil. $\mathrm{Re}$ gardless of the binder content, the $\mathrm{pH}$ value gradually decreases with increasing curing times. $\mathrm{pH}$ decreased with time for the treated soil due to more production of $\mathrm{CSH}$ or $\mathrm{CAH}$ gels as a results from pozzolanic reactions. Consumption of

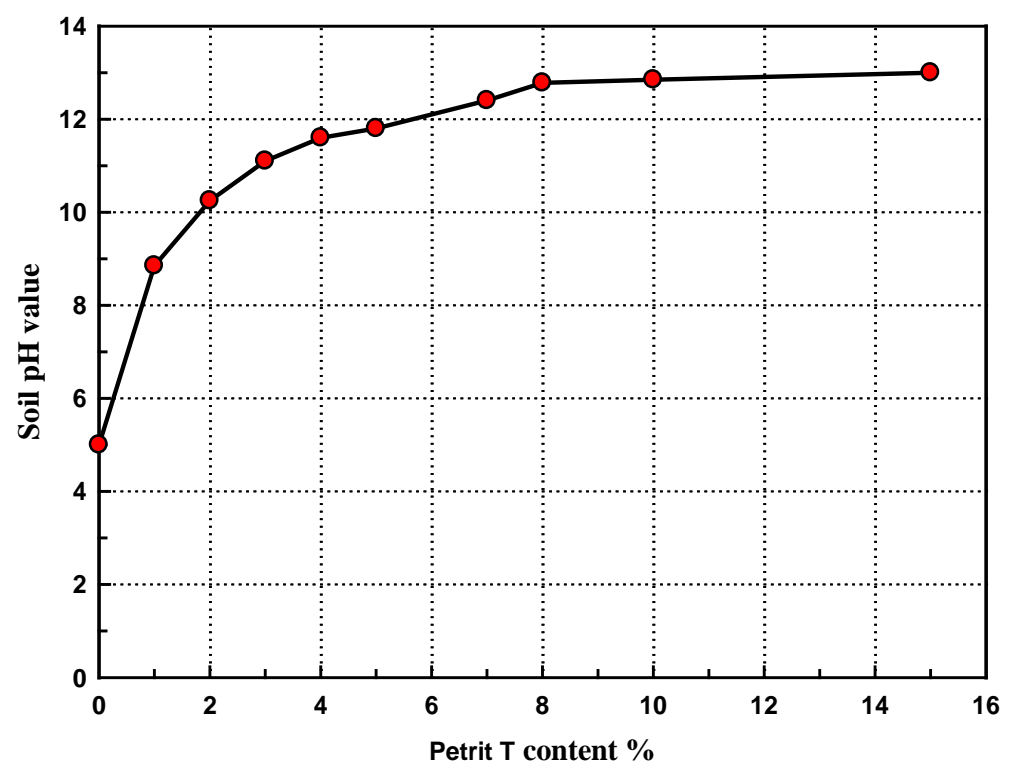

Figure 11. Immediate change in soil $\mathrm{pH}$ value versus Petirt $\mathrm{T}$ content.

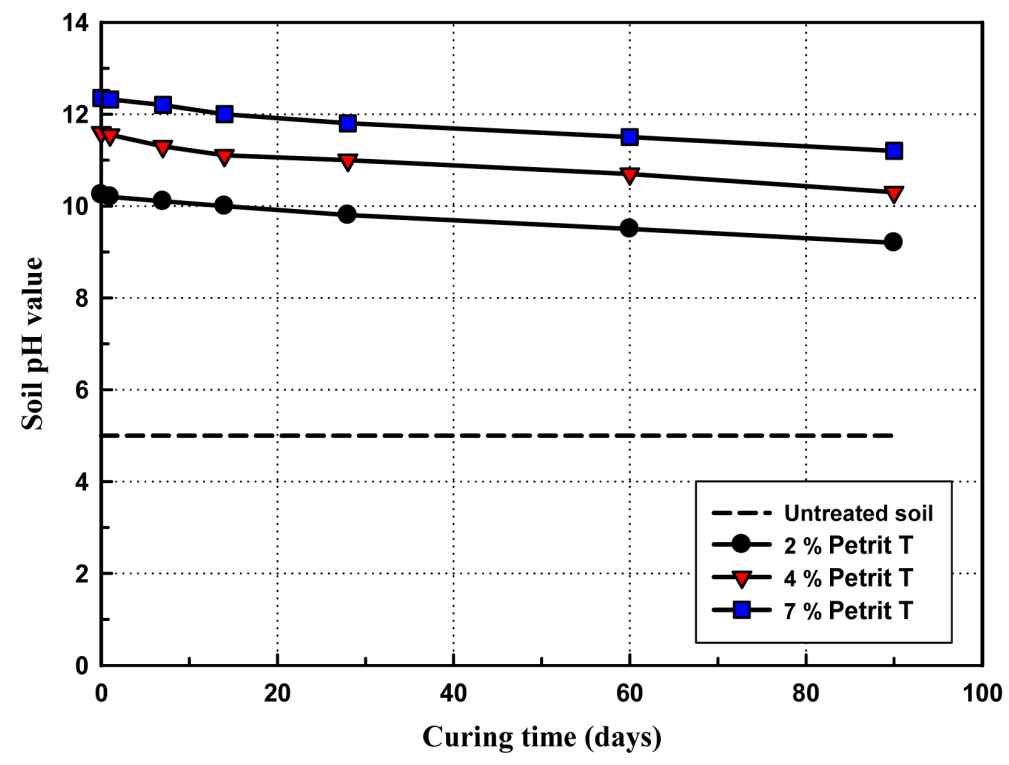

Figure 12. Effect of curing time and Petrit $\mathrm{T}$ content on the $\mathrm{pH}$ value of treated soil. 
$(\mathrm{OH}-)$ is the main reason for the decrease in $\mathrm{pH}$. Reducing $\mathrm{pH}$ over curing time is consisted with [24] [50].

\subsection{Unconfined Compressive Strength (UCS)}

Unconfined compressive strength tests were conducted on untreated and treated soil samples, prepared in identical way. Figure 13(a) shows the unconfined compression strength $\left(\mathrm{q}_{\mathrm{u}}\right)$ for the untreated soil at various curing time.

Figures 13(b)-(d) show the effect on soil strength for different amounts of Petrit $\mathrm{T}$ added to the original clay. The major components of Petrit $\mathrm{T}$ are dicalcium silicate (DCS) and calcium-silicon-aluminate (CSA). The DCS is similar to the clinker mineral $\mathrm{C}_{2} \mathrm{~S}$ (belite) in Portland cement, which is responsible for gaining strength over a relatively long curing period due to the lower reactivity. Therefore, the $\mathrm{C}_{2} \mathrm{~S}$ reaction can explain the strength development due to production of calcium-silicate hydrate $(\mathrm{CSH})$ gel. This binds soil particles together and produces a strong and hard mixture over time [24]. In addition, calcium hydroxide $\mathrm{Ca}(\mathrm{OH})_{2}$ is also formed as a result of the hydration reaction of $\mathrm{C}_{2} \mathrm{~S}$, which leads to an increase in $\mathrm{pH}$ value as discussed earlier. Moreover, the
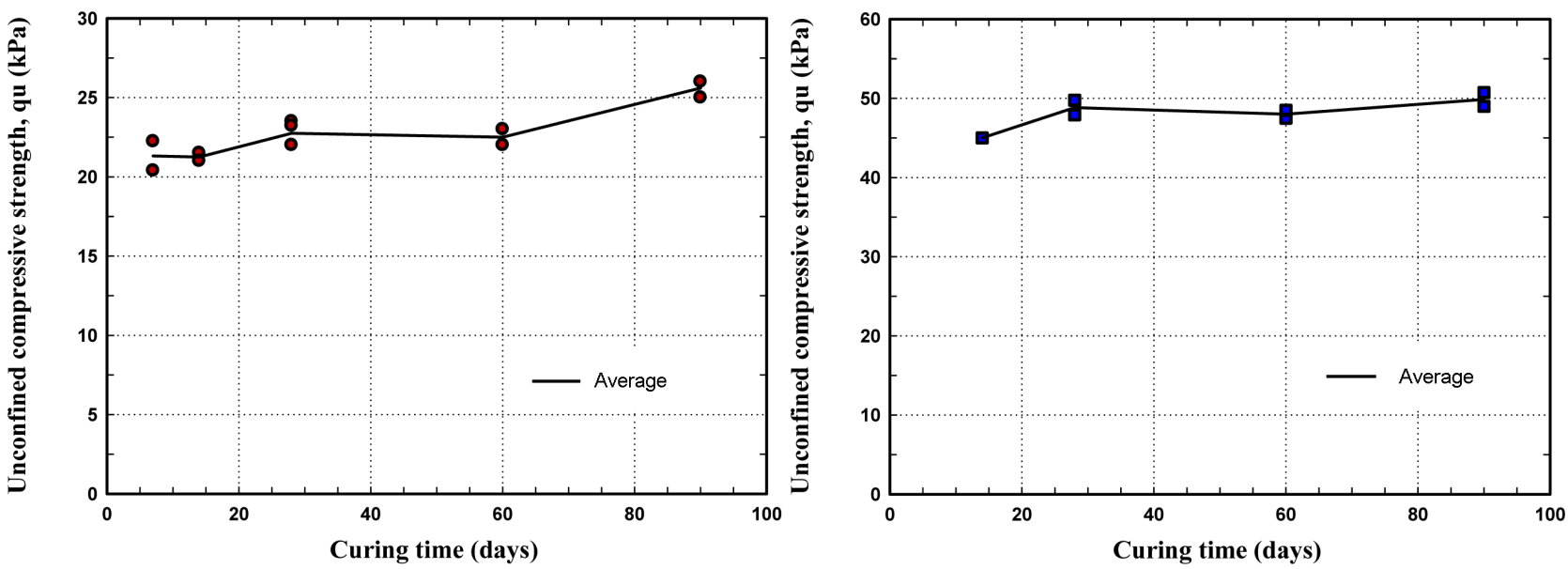

(a) Untreated soil

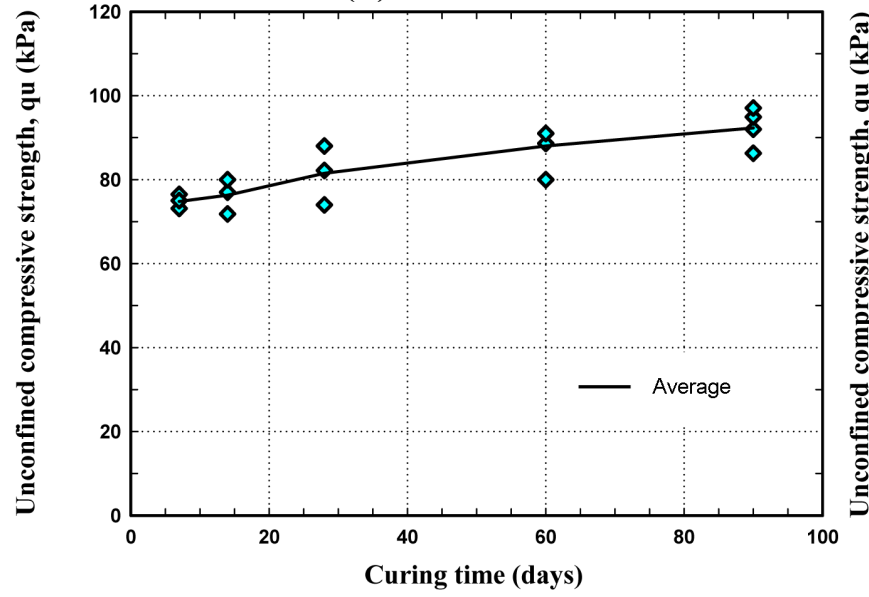

(c) $4 \%$ Petrit $\mathrm{T}$

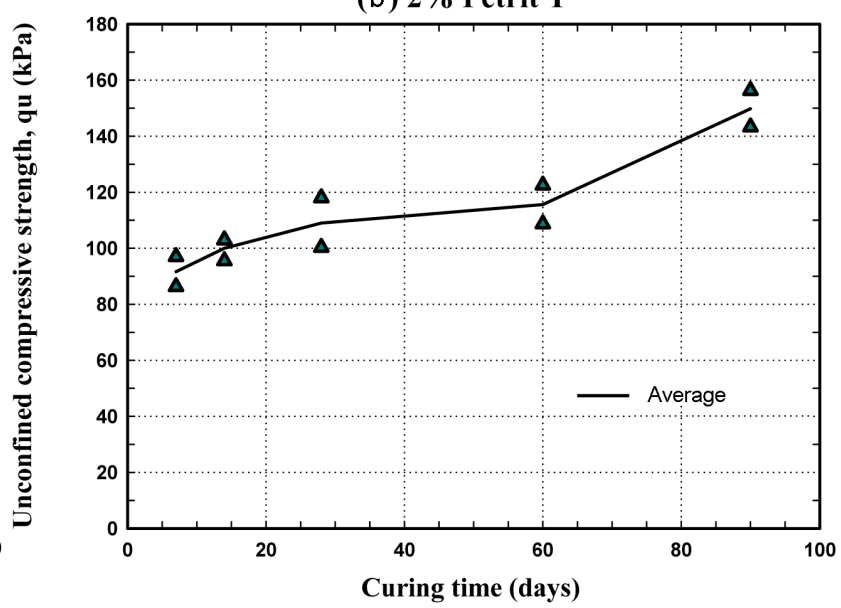

(d) $7 \%$ Petrit $\mathrm{T}$

Figure 13. Unconfied compresion strenght versus curing time for different Petrit $\mathrm{T}$ content for all tests. 
pozzolanic reactions start to dissolve silica-aluminium from clay minerals and provide additional cementitious products of CSH and CASH gel. CSH gel is the most common product from the hydration and pozzolanic reactions leads to enhanced strength of the stabilized soil. Reactions of $\mathrm{C}_{2} \mathrm{~S}$ and hydrated lime are illustrated in Equations (2), (3) and (4) [24] [33] [51].

$$
\begin{gathered}
2 \mathrm{C}_{2} \mathrm{~S}+5 \mathrm{H} \rightarrow \mathrm{C}_{3} \mathrm{~S}_{2} \mathrm{H}_{4}+\mathrm{CH} \\
\mathrm{CH}+\mathrm{S}+\mathrm{H} \rightarrow \mathrm{CSH} \\
\mathrm{CH}+\mathrm{A}+\mathrm{H} \rightarrow \mathrm{CASH}
\end{gathered}
$$

where $\mathrm{C}, \mathrm{S}, \mathrm{A}, \mathrm{H}$, and $\mathrm{CH}$ are the abbreviations for calcium $(\mathrm{CaO})$, silicate $\left(\mathrm{SiO}_{2}\right)$, aluminate $\left(\mathrm{Al}_{2} \mathrm{O}_{3}\right)$, water $\left(\mathrm{H}_{2} \mathrm{O}\right)$ and calcium hydroxide $\left(\mathrm{Ca}(\mathrm{OH})_{2}\right)$ respectively.

The strength of the treated soil increases by increasing the Petrit $\mathrm{T}$ content and curing time. This indicates the producing a new cementing materials such as calcium silicate hydrate $(\mathrm{CSH})$ and calcium aluminate hydrate $(\mathrm{CASH})$ gels during the pozzolanic reactions. At low binder content (2\%), soil strength improved during the first 28 days of curing time, but there was almost no further improvement visible after 60 and 90 days (see Figure 13(b)). An increase in soil strength is related to the production of primary cementing materials from hydration reaction, which binds soil particles together and hardens over time. Moreover, the $\mathrm{pH}$ value of treated soil can explain the lack of increase in soil strength after 28 days. For the 60 and 90 days curing time, it was found that the $\mathrm{pH}$ concentrations were 9.5 and 9 respectively (see Figure 12).

According to [10] [50] [52] [53], treated soil with $\mathrm{pH}$ value higher than 10 could be enough for continuous dissolving of silicates and aluminate in the soil to produce stabilizing component. For this reason, a long curing periods for samples mixed with only $2 \%$ of binder has no additional effect on strength as the $\mathrm{pH}$ value is below 10 .

Soil strength gradually increased with time when the Petrit $\mathrm{T}$ content was increased from $2 \%$ to $4 \%$. A similar trend has been observed after 60 days curing time when the binder content is increased from $4 \%$ to $7 \%$. This is related to the provision of more $\mathrm{C}_{2} \mathrm{~S}$, leading to the production of more $\mathrm{CSH}$ and $\mathrm{CAH}$ during the pozzolanic reactions when using relatively high amounts of binder (7\%). In addition to this the $\mathrm{pH}$ values were high as shown in Figure 12.

The increase in soil strength after treatment is expressed as the ratio between the strength of the treated to untreated soil. Based on this, adding $2 \%, 4 \%$, and $7 \%$ of Petrit $\mathrm{T}$ binder increase the soil strength 2,4 and 6.5 times respectively after 90 days curing time.

\subsection{Consistency Limit-UCS Relationship}

The addition of Petrit T reduces the water content (see Figure 7 and Figure 8). Thus, the ratio of water content to the plastic limit can have a major effect on the relationship between consistency limits and the unconfined compression strength. Figure 14 shows the increase in unconfined compression strength with 


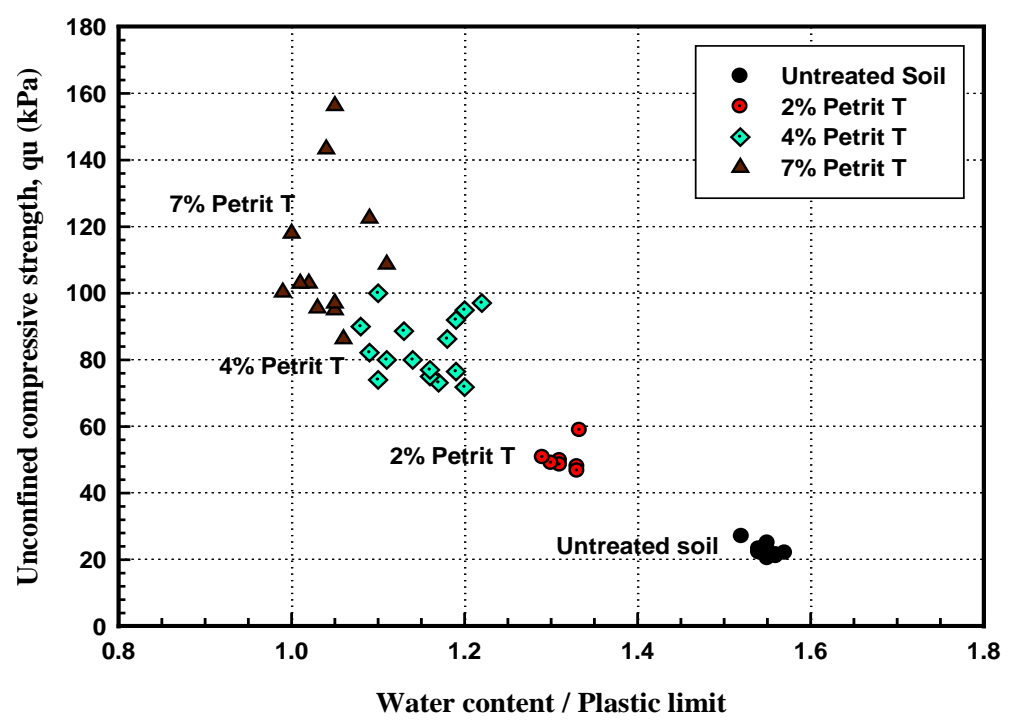

Figure 14. UCS versus water/plastic limit ratio for all tests.

a decrease in the water to plastic limit ratio. A scattered pattern is observed, especially when the water/plastic limit ratio approaches 1 (see Figure 14).

\subsection{Stress-Strain Curves}

For different amount of Petrit $\mathrm{T}$ and curing times, stress-strain behaviors for the untreated and treated soils are presented in Figure 15. It is seen that the untreated soil has a low peak stress of $23 \mathrm{kPa}$ reached at $24 \%$ of strain. As the Petrit $\mathrm{T}$ content increases, the peak strength increases. Failure strain, corresponding to the peak stress, decreases with an increase in binder content. At peak stresses, small cracks can be clearly observed on the surface of the specimen.

A significant change in the stress-strain curves can be noticed for high Petrit $\mathrm{T}$ content (7\%) and long curing period (90 days). A more brittle failure than for lower binder contents is observed (Figure 15(d)). The failure mode gradually changes from ductile to brittle failure as binder content increases and it is the binder content and curing time that have the major effects on the stress-strain curves [30] [54].

\subsection{Strain at Failure}

The addition of Petrit $\mathrm{T}$ significantly reduced failure strain from $24 \%$ for the untreated soil to $14 \%$ and lower at $2 \%, 4 \%$ and $7 \%$ petrit $\mathrm{T}$ contents (see Figure 16). The failure strain is almost constant independent of curing time.

Figure 17 shows the failure strains versus unconfined compressive strengths (qu) for all specimens and curing times. When the Petrit $\mathrm{T}$ content increases, strength increases and strain at failure decreases. A scattered pattern in measured failure strain is observed at low strengths ( $22 \mathrm{kPa}$ for untreated soil), which might be attributed to the method of sample preparation involved. Moreover, a significant reduction in strain at failure was observed regarding different Petrit $\mathrm{T}$ treatments from $2 \%$ to $7 \%$, which led to an increased soil strength of up to 150 $\mathrm{kPa}$ (see Figure 17). 


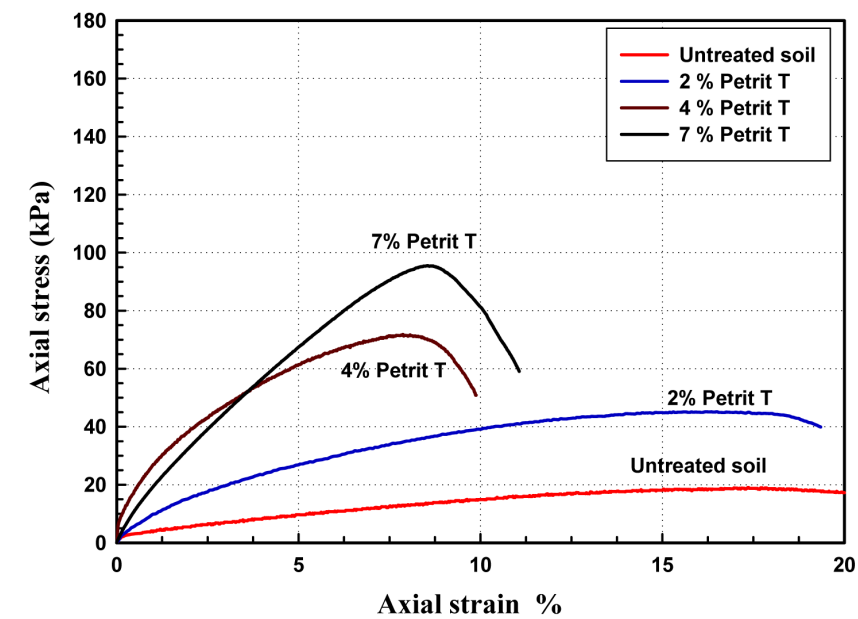

(a) 14 dyas curing time

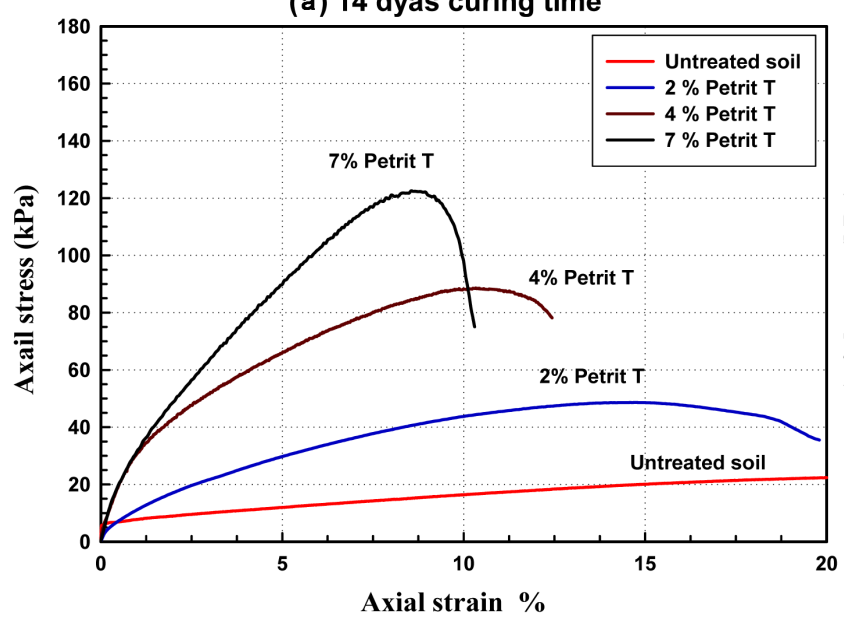

(c) 60 dyas curing time

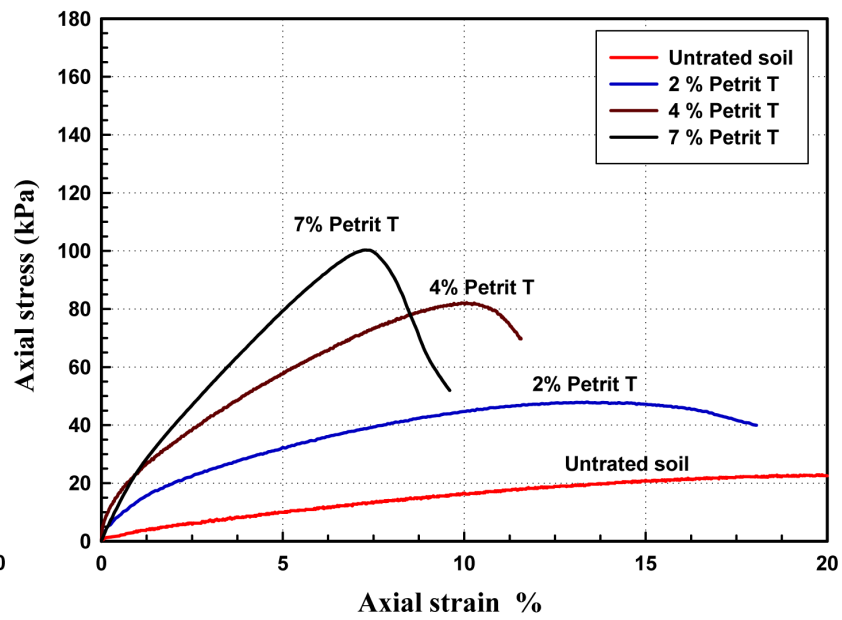

(b) 28 dyas curing time

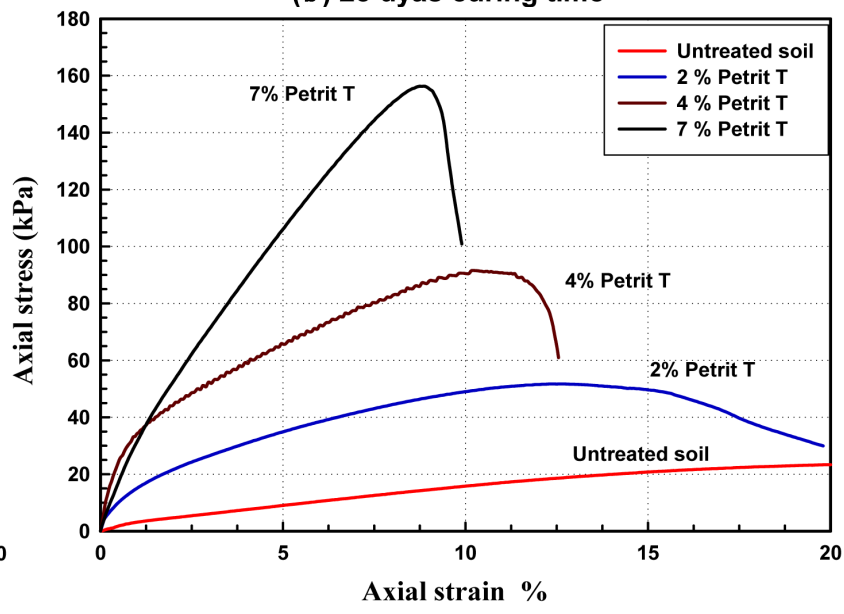

(d) 90 dyas curing time

Figure 15. Stress-strain curves for untreated and treated soil with different Petrit $\mathrm{T}$ contents and curing time.

\subsection{Stiffness of Treated Soil}

The effects of adding Petrit $\mathrm{T}$ and curing times on the soil stiffness are shown in Figure 18. The stiffness is defined by a secant modulus $\left(\mathrm{E}_{50}\right)$ for the tested specimens. $\mathrm{E}_{50}$ is evaluated from the stress-strain curve at $50 \%$ of the maximum unconfined compressive strength (qu). Figure 18 shows that the stiffness increases with an increase in binder content and curing times. This can be related to the production of cementitious materials as a result of the hydration and pozzolanic reactions. Higher binder content produces more cementing components and vice versa.

An increase in soil stiffness can be explained by the ratio between the stiffness of the treated samples to the stiffness of the untreated soil samples. Based on this, adding $2 \%, 4 \%$ and $7 \%$ of Petrit $\mathrm{T}$ improves the soil stiffness approximately 4, 10 and 15 times respectively when compared to untreated soil after 90 days curing time.

The relationship between unconfined compression strength and the modulus of elasticity, $\mathrm{E}_{50}$, is shown in Figure 19. An increase in soil stiffness was observed with an increase in soil strength. Based on the results shown in Figure 19, the 


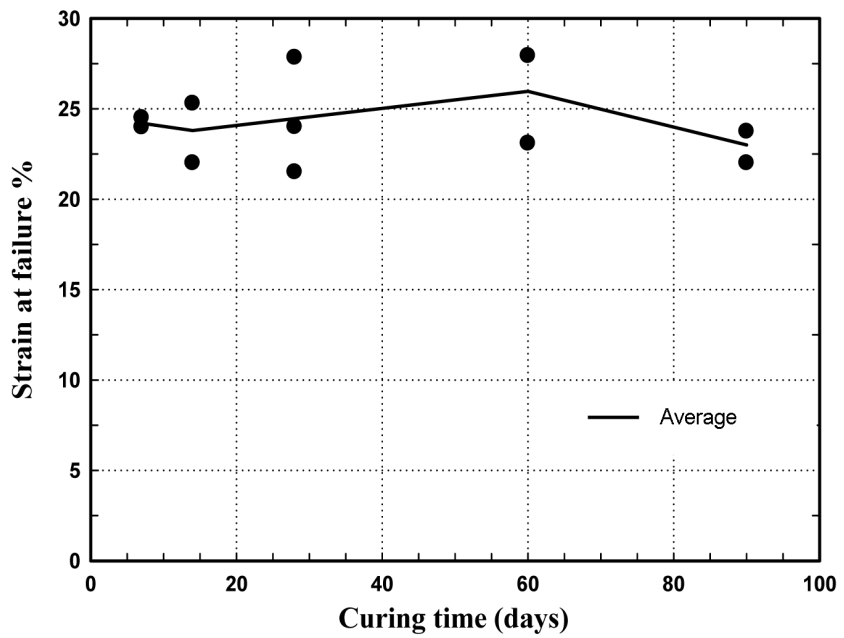

(a) Untreated soil

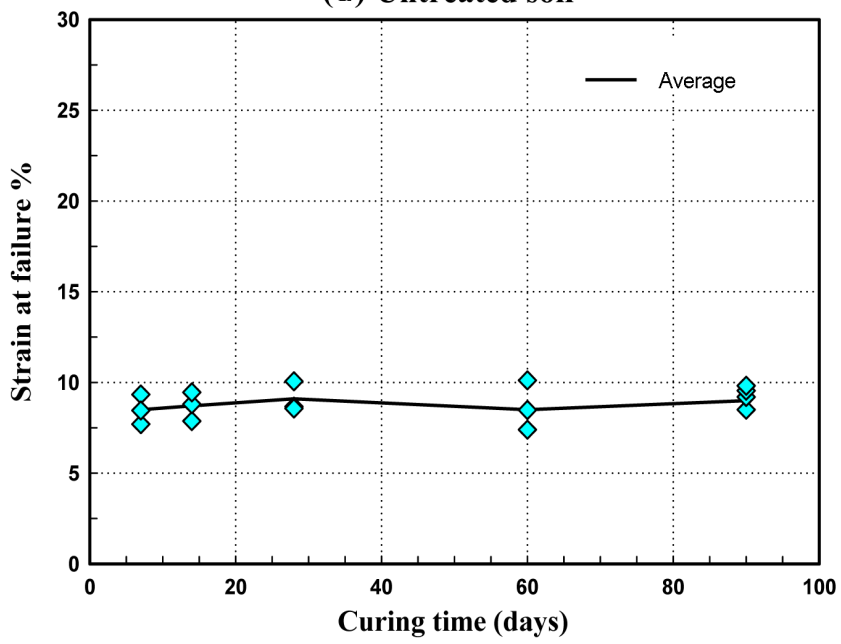

(c) $4 \%$ Petrit $\mathrm{T}$

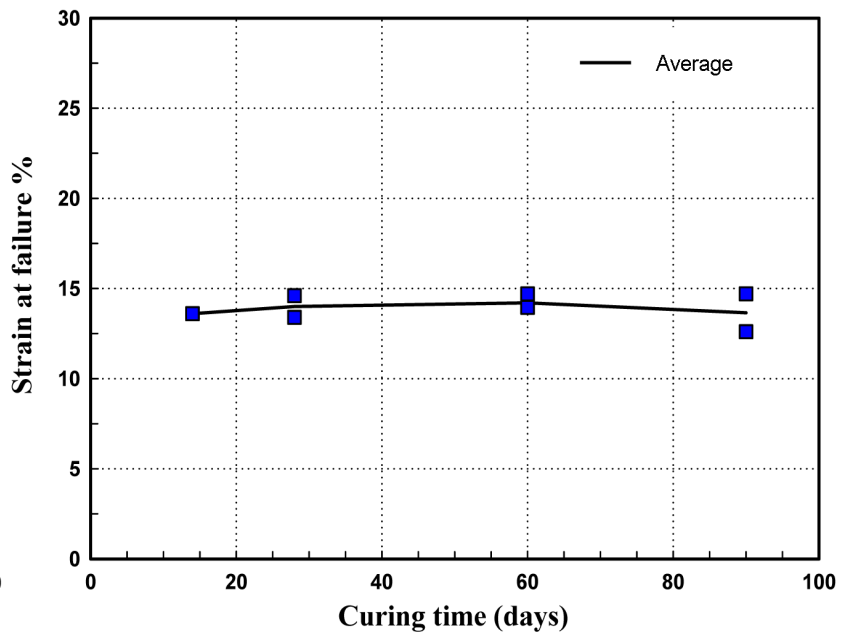

(b) $2 \%$ Petrit $\mathrm{T}$

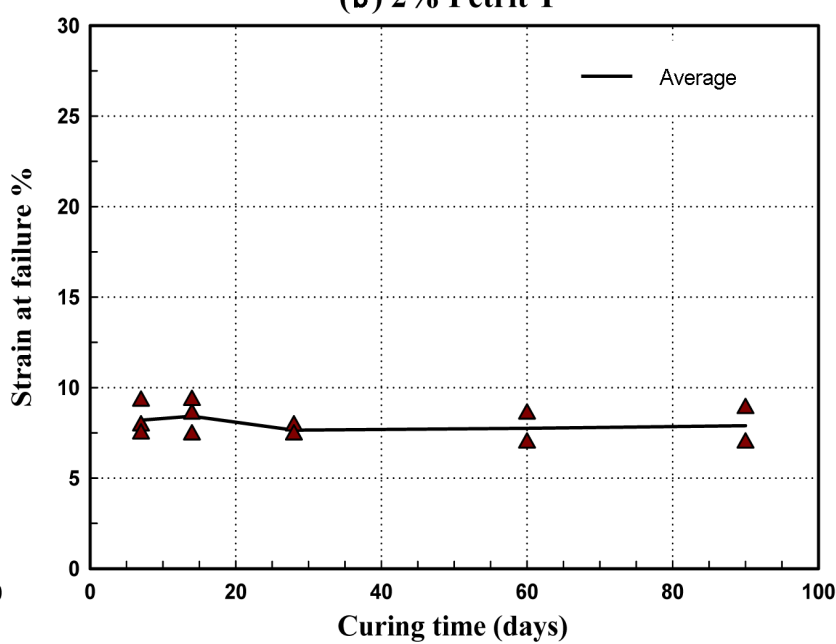

(d) $7 \%$ Petrit $\mathrm{T}$

Figure 16. Strain at failure versus curing time and Petrit $\mathrm{T}$ content for all tests.

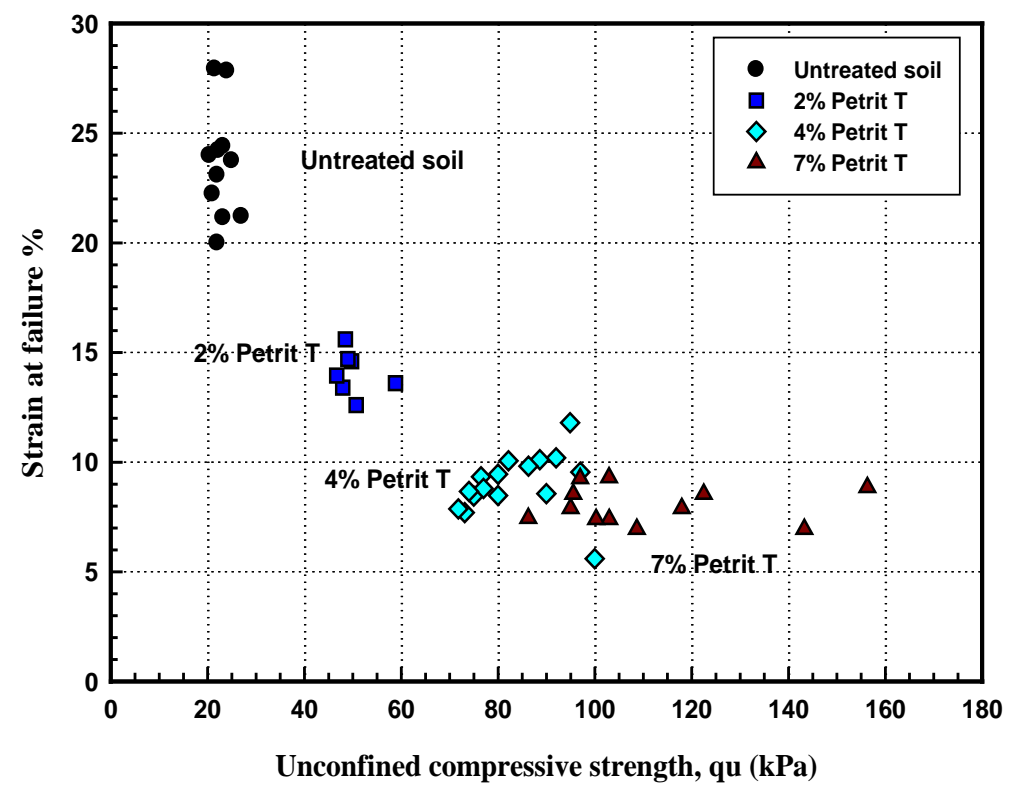

Figure 17. Strain at failure versus UCS strength. 


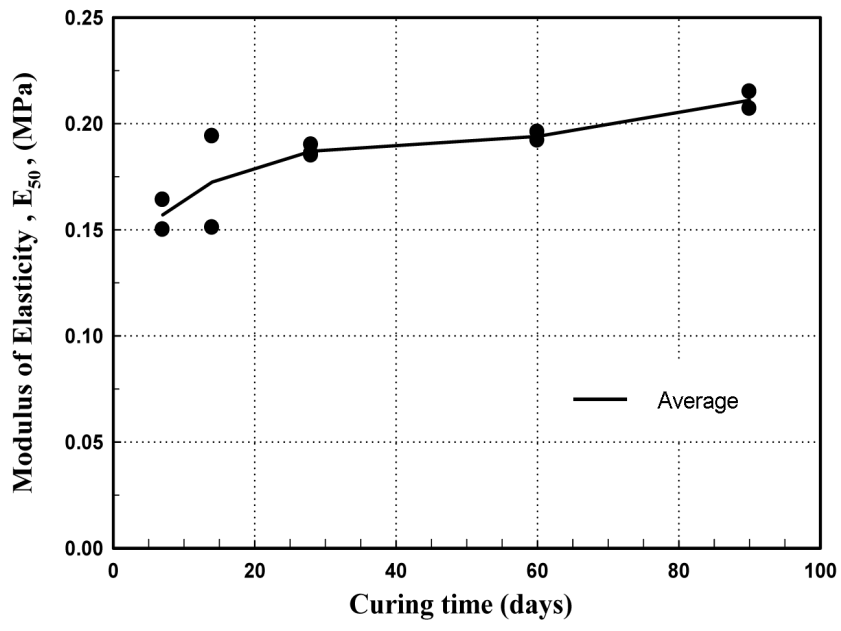

(a) Untreated Soil

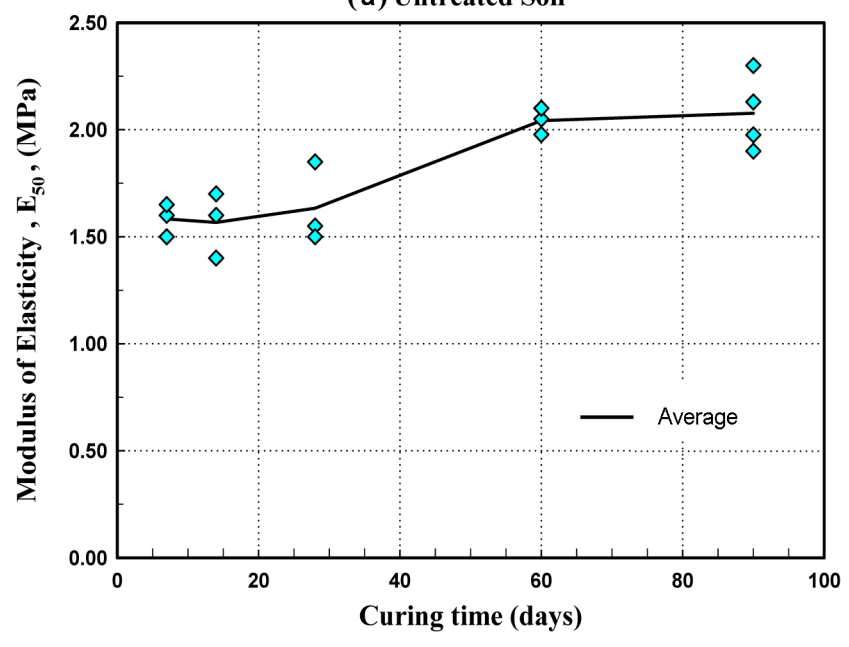

(c) $4 \%$ Petrit $\mathrm{T}$

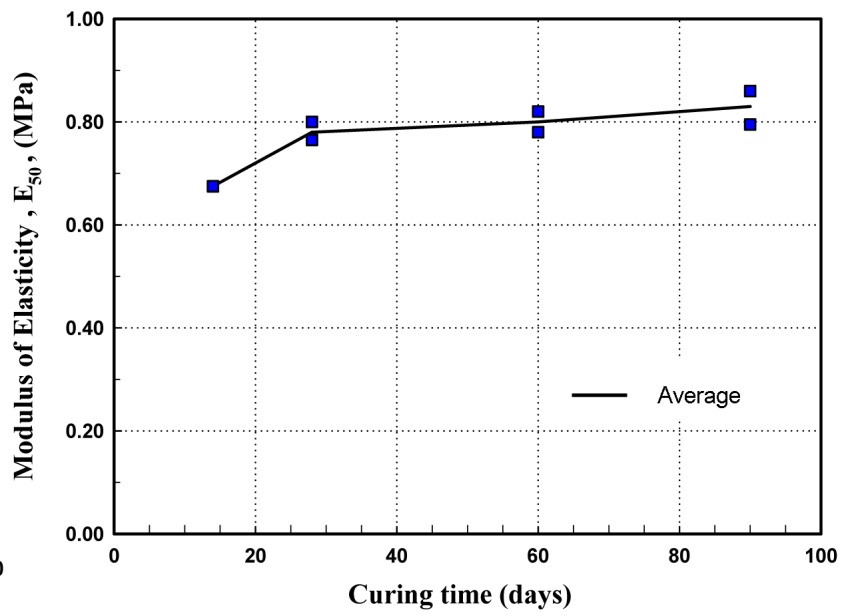

(b) $2 \%$ Petrit $\mathrm{T}$

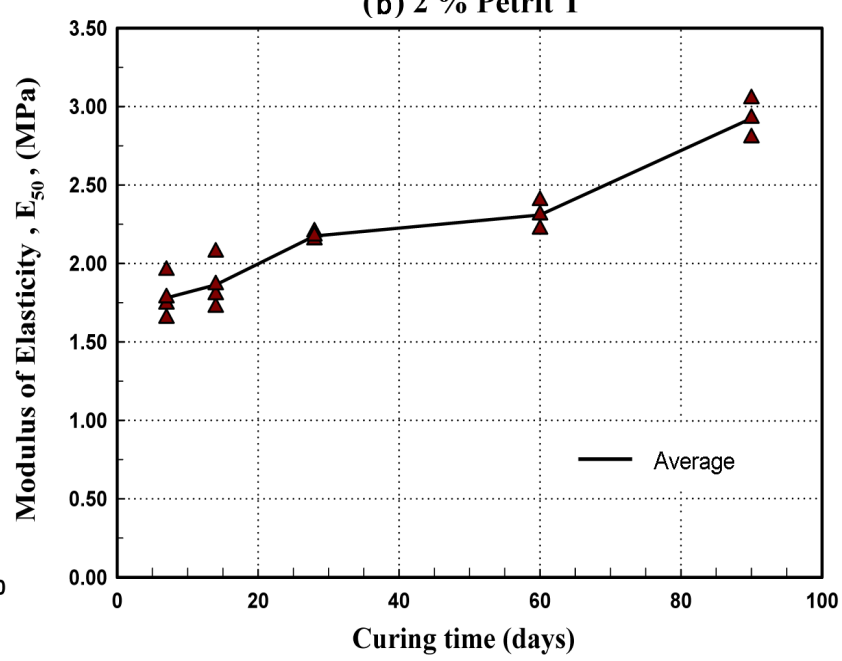

(d) $7 \%$ Petrit $\mathrm{T}$

Figure 18. Modulus of elasticity versus curing time and binder content for all tests.

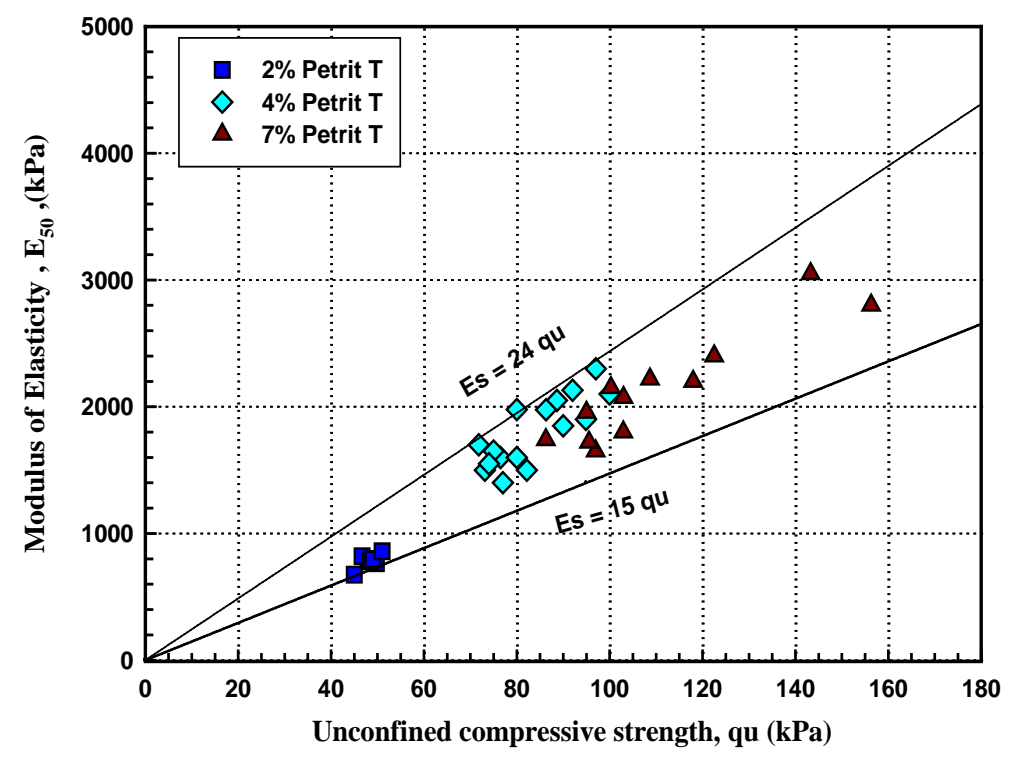

Figure 19. Modulus of elasticity versus UCS strength for different binder contents and length of curing periods. 
modulus of elasticity can be estimated between $\mathrm{E}_{50}=15 \mathrm{qu}$ and $\mathrm{E}_{50}=24 \mathrm{qu}$.

Mmany authors [42] [45] [54] [55] [56] have obtained a variable conclusion about the relationship between $\mathrm{E}_{50}$ and qu for a wider range of binders. The comparisons between previous studies and present results are summarized in Table 4. The results obtained from this study are lower than those obtained in previous studies. This is due to the use of small amounts of binder as well as due to the binder type.

\section{Conclusions}

In this study, the modification and improvement of clayey silt soil treated with low content of Petrit $\mathrm{T}(\leq 7 \%)$ was investigated. The following conclusions can be drawn from the present study.

- Small amounts of Petrit T increase strength and stiffness of treated soil. Soil strength and stiffness increase with curing times when higher binder content (7\%) is used.

- The plasticity index decreases over time, even for very low binder content. Thus, Petrit T added to soil better workability.

- Petrit T has the immediate effect of increasing the solidification of soil after treatment and with time. Water content is reduced and is close to the plastic limit after treatment. Petrit $\mathrm{T}$ can be used as a drying agent in order to reduce the initial water content of soil to facilitate the workability and compaction processes for various engineering purposes.

- Failure strain decreases with an increase in binder content and curing time, leading to a gradual change in failure mode from ductile to brittle behavior.

- $\mathrm{pH}$ value provides useful assessment information to describe soil binder reactions. A pH value lower than 9 is not sufficient to initialize the pozzolanic reaction and leads to a lack of improved soil strength for the long curing periods.

The findings of this study show clearly that Perit $\mathrm{T}$ can be used as a binder to stabilize soil and thus will be effective in replacing cement as binder if the requirements on stiffness and strength are not as high. The findings confirm further that using smaller percentages of binder still has a significant effect on the behavior of the clay used in this study. Further investigations will focus on other

Table 4. Comparison between the relationship of elastic modulus $\left(\mathrm{E}_{50}\right)$ and UCS (qu).

\begin{tabular}{|c|c|c|}
\hline Material & $\begin{array}{l}\text { Upper and lower range of soil } \\
\text { stiffness times qu }\end{array}$ & Reference \\
\hline Three soil types (silt, silty clay and laterite) treated with cement (7\% - 13\%) in Malaysia & $\mathrm{E}_{50}=(100-326) \mathrm{qu}$ & {$[55]$} \\
\hline Swedish clay treated with cement and lime $\left(200 \mathrm{~kg} / \mathrm{m}^{3}(18 \%-24 \%)\right)$ & $E_{50}=(53-92) q u$ & [56] \\
\hline Bangkok soft clay with high water content treated with cement $(5 \%-35 \%)$ and fly ash $(5 \%-30 \%)$ & $\mathrm{E}_{50}=(96-129) \mathrm{qu}$ & [45] \\
\hline Swedish clayey silt soil treated with cement $(1 \%-7 \%)$ & $\mathrm{E}_{50}=(16-85) q u$ & {$[42]$} \\
\hline Swedish clayey silt soil treated with Petrtit T (2\% - 7\%) & $\mathrm{E}_{50}=(14-24) \mathrm{qu}$ & Present study \\
\hline
\end{tabular}


binders as the reduction in cement content will contribute significantly to the environmental balance and to saving money for construction.

\section{Acknowledgements}

The authors would like to express their thanks to Iraqi Ministry of Higher Education for sponsoring the first author with a grant.

\section{References}

[1] Saadeldin, R. and Siddiqua, S. (2013) Geotechnical Characterization of a Clay-Cement Mix. Bulletin of Engineering Geology and the Environment, 72, 601-608. https://doi.org/10.1007/s10064-013-0531-2

[2] Keshawarz, M.S. and Dutta, U. (1993) Stabilization of South Texas Soils with Fly Ash. Fly Ash for Soil Improvement, ASCE Geotechnical Special Publication No. 36.

[3] Kaniraj, S.R. and Havanagi, V.G. (1999) Compressive Strength of Cement Stabilized Fly Ash-Soil Mixtures. Cement and Concrete Research, 29, 673-677. https://doi.org/10.1016/S0008-8846(99)00018-6

[4] Parsons, R.L. and Kneebone, E. (2005) Field Performance of Fly Ash Stabilized Subgrades. Proceedings of the Institution of Civil Engineers-Ground Improvement, 9 , 33-38. https://doi.org/10.1680/grim.2005.9.1.33

[5] McCarthy, J.E. (1994) Soil Stabilization for Pavements. Department of the Army and Air Force of United States, USA.

[6] Edil, T.B., Acosta, H.A. and Benson, C.H. (2006) Stabilizing Soft Fine-Grained Soils with Fly Ash. Journal of Materials in Civil Engineering, 18, 283-294. https://doi.org/10.1061/(ASCE)0899-1561(2006)18:2(283)

[7] Puppala, A.J. (2016) Advances in Ground Modification with Chemical Additives: From Theory to Practice. Transportation Geotechnics, 9, 123-138. https://doi.org/10.1016/j.trgeo.2016.08.004

[8] Kamon, M. and Nontananandh, S. (1991) Combining Industrial Wastes with Lime for Soil Stabilization. Journal of Geotechnical Engineering, 117, 1-17. https://doi.org/10.1061/(ASCE)0733-9410(1991)117:1(1)

[9] Tao, M. and Zhang, Z. (2005) Enhanced Performance of Stabilized By-Product Gypsum. Journal of Materials in Civil Engineering, 17, 617-623. https://doi.org/10.1061/(ASCE)0899-1561(2005)17:6(617)

[10] Sargent, P., Hughes, P.N., Rouainia, M. and Glendinning, S. (2012) Soil Stabilisation Using Sustainable Industrial By-Product Binders and Alkali Activation. GeoCongress 2012: State of the Art and Practice in Geotechnical Engineering, 948-957. https://doi.org/10.1061/9780784412121.098

[11] Horpibulsuk, S., Phetchuay, C. and Chinkulkijniwat, A. (2011) Soil Stabilization by Calcium Carbide Residue and Fly Ash. Journal of Materials in Civil Engineering, 24, 184-193. https://doi.org/10.1061/(ASCE)MT.1943-5533.0000370

[12] Horpibulsuk, S., Phetchuay, C., Chinkulkijniwat, A. and Cholaphatsorn, A. (2013) Strength Development in Silty Clay Stabilized with Calcium Carbide Residue and Fly Ash. Soils and Foundations, 53, 477-486. https://doi.org/10.1016/j.sandf.2013.06.001

[13] Jiang, N.J., Du, Y.J., Liu, S.Y., Wei, M.L., Horpibulsuk, S. and Arulrajah, A. (2015) Multi-Scale Laboratory Evaluation of the Physical, Mechanical, and Microstructural Properties of Soft Highway Subgrade Soil Stabilized with Calcium Carbide Residue. Canadian Geotechnical Journal, 53, 373-383. https://doi.org/10.1139/cgj-2015-0245 
[14] Sezer, A., İnan, G., Yılmaz, H.R. and Ramyar, K. (2006) Utilization of a Very High Lime Fly Ash for Improvement of Izmir Clay. Building and Environment, 41, 150155. https://doi.org/10.1016/j.buildenv.2004.12.009

[15] Kolias, S., Kasselouri-Rigopoulou, V. and Karahalios, A. (2005) Stabilisation of Clayey Soils with High Calcium Fly Ash and Cement. Cement and Concrete Composites, 27, 301-313. https://doi.org/10.1016/j.cemconcomp.2004.02.019

[16] Athanasopoulou, A. (2013) Addition of Lime and Fly Ash to Improve Highway Subgrade Soils. Journal of Materials in Civil Engineering, 26, 773-775. https://doi.org/10.1061/(ASCE)MT.1943-5533.0000856

[17] Hossain, K.M., Lachemi, M. and Easa, S. (2006) Characteristics of Volcanic Ash and Natural Lime Based Stabilized Clayey Soils. Canadian Journal of Civil Engineering, 33, 1455-1458. https://doi.org/10.1139/106-099

[18] Haase, B. (2014) General Information about Petrit T. Internal Report. Höganäs Sweden AB, Report No.: PM.

[19] Standard, A.S.T.M. (2011) D2487-11 Standard Practice for Classification of Soils for Engineering Purposes (Unified Soil Classification System). ASTM International, West Conshohocken, PA.

[20] Larsson, R. (2008) Jords Egenskaper. Statens Geotekniska Institut, Linköping. (In Swedish)

[21] Standard, A.S.T.M. (2014) D2974-14 Standard Test Methods for Moisture, Ash, and Organic Matter of Peat and Other Organic Soils. ASTM International, West Conshohocken, PA.

[22] Huang, P.T., Patel, M., Santagata, M.C. and Bobet, A. (2009) Classification of Organic Soils. Joint Transportation Research Program, Indiana Department of Transportation and Purdue University, West Lafayette, Indiana Publication FHWA/IN/ JTRP-2008/02.

[23] Karlsson, R. and Hansbo, S. (1989) Soil Classification and Identification, D8. Swedish Council for Building Research, Stockholm, 49.

[24] Janz, M. and Johansson, S.E. (2002) The Function Of Different Binding Agents in Deep Stabilization. Swedish Deep Stabilization Research Centre, Report, 9, 1-35.

[25] Swedish Standard Commission (1990) Geotechnical Tests-Cone Liquid Limit. Swedish Standards Commission, Stockholm, SS 027120. (In Swedish)

[26] Swedish Standard Commission (1990) Geotechnical Tests-Plastic Limit. Swedish Standards Commission, Stockholm, SS 027120. (In Swedish)

[27] Standard, A.S.T.M. (2016) Standard Test Method for pH of Soils. ASTM International, West Conshohocken, PA.

[28] Eskisar, T. (2015) Influence of Cement Treatment on Unconfined Compressive Strength and Compressibility of Lean Clay with Medium Plasticity. Arabian Journal for Science \& Engineering (Springer Science \& Business Media BV), 40, 763-772. https://doi.org/10.1007/s13369-015-1579-Z

[29] Baran, B., Ertürk, T., Sarıkaya, Y. and Alemdaroğlu, T. (2001) Workability Test Method for Metals Applied to Examine a Workability Measure (Plastic Limit) for Clays. Applied Clay Science, 20, 53-63. https://doi.org/10.1016/S0169-1317(01)00042-4

[30] Mallela, J., Quintus, H.V. and Smith, K.L. (2004) Consideration of Lime-Stabilized Layers in Mechanistic-Empirical Pavement Design. The National Lime Association, 200-208.

[31] Sariosseiri, F. and Muhunthan, B. (2009) Effect of Cement Treatment on Geotechnical Properties of Some Washington State Soils. Engineering Geology, 104, 119 - 
125. https://doi.org/10.1016/j.enggeo.2008.09.003

[32] Sivapullaiah, P.V., Sridharan, A. and Bhaskar Raju, K.V. (2000) Role of Amount and Type of Clay in the Lime Stabilization of Soils. Proceedings of the Institution of $\mathrm{Ci}^{-}$ vil Engineers-Ground Improvement, 4, 37-45. https://doi.org/10.1680/grim.2000.4.1.37

[33] Kinuthia, J.M., Wild, S. and Jones, G.I. (1999) Effects of Monovalent and Divalent Metal Sulphates on Consistency and Compaction of Lime-Stabilised Kaolinite. Applied Clay Science, 14, 27-45. https://doi.org/10.1016/S0169-1317(98)00046-5

[34] Åhnberg, H., Johansson, S.E., Pihl, H. and Carlsson, T. (2003) Stabilising Effects of Different Binders in Some Swedish Soils. Proceedings of the Institution of Civil Engineers-Ground Improvement, 7, 9-23. https://doi.org/10.1680/grim.2003.7.1.9

[35] Horpibulsuk, S., Rachan, R. and Raksachon, Y. (2009) Role of Fly Ash on Strength and Microstructure Development in Blended Cement Stabilized Silty Clay. Soils and Foundations, 49, 85-98. https://doi.org/10.3208/sandf.49.85

[36] Locat, J., Trembaly, H. and Leroueil, S. (1996) Mechanical and Hydraulic Behaviour of a Soft Inorganic Clay Treated with Lime. Canadian Geotechnical Journal, 33, 654-669. https://doi.org/10.1139/t96-090-311

[37] Chew, S.H., Kamruzzaman, A.H.M. and Lee, F.H. (2004) Physicochemical and Engineering Behavior of Cement Treated Clays. Journal of Geotechnical and Geoenvironmental Engineering, 130, 696-706. https://doi.org/10.1061/(ASCE)1090-0241(2004)130:7(696)

[38] Bin-Shafique, S., Rahman, K., Yaykiran, M. and Azfar, I. (2010) The Long-Term Performance of Two Fly Ash Stabilized Fine-Grained Soil Subbases. Resources, Conservation and Recycling, 54, 666-672. ttps://doi.org/10.1016/j.resconrec.2009.11.007

[39] Asgari, M.R., Dezfuli, A.B. and Bayat, M. (2015) Experimental Study on Stabilization of a Low Plasticity Clayey Soil with Cement/Lime. Arabian Journal of Geosciences, 8, 1439-1452. https://doi.org/10.1007/s12517-013-1173-1

[40] Sivapullaiah, P.V., Prashanth, J.P. and Sridharan, A. (1996) Effect of Fly Ash on the Index Properties of Black Cotton Soil. Soils and Foundations, 36, 97-103. https://doi.org/10.3208/sandf.36.97

[41] Maher, A., Bennert, T., Jafari, F., Douglas, W. and Gucunski, N. (2004) Geotechnical Properties of Stabilized Dredged Material from New York-New Jersey Harbor. Transportation Research Record: Journal of the Transportation Research Board, 1874, 86-96. https://doi.org/10.3141/1874-10

[42] Al-Jabban, W., Knutsson, S., Al-Ansari, N. and Laue, J. (2017) Modification-Stabilization of Clayey Silt Soil Using Small Amounts of Cement. Earth Sciences and Geotechnichal Engineering, 7, 77-96.

[43] Mackiewicz, S.M. and Ferguson, E.G. (2005) Stabilization of Soil with Self-Cementing Coal Ashes. World of Coal Ash (WOCA), 1-7.

[44] Misra, A. (2000) Utilization of Western Coal Fly Ash in Construction of Highways in the Midwest (No. MATC UMC 96-2). University of Nebraska, Mid-America Transportation Center.

[45] Jongpradist, P., Jumlongrach, N., Youwai, S. and Chucheepsakul, S. (2009) Influence of Fly Ash on Unconfined Compressive Strength of Cement-Admixed Clay at High Water Content. Journal of Materials in Civil Engineering, 22, 49-58. https://doi.org/10.1061/(ASCE)0899-1561(2010)22:1(49)

[46] Kang, X., Kang, G.C., Chang, K.T. and Ge, L. (2014) Chemically Stabilized Soft Clays for Road-Base Construction. Journal of Materials in Civil Engineering, 27, 
Article ID: 04014199.

[47] Horpibulsuk, S., Rachan, R., Chinkulkijniwat, A., Raksachon, Y. and Suddeepong, A. (2010) Analysis of Strength Development in Cement-Stabilized Silty Clay from Microstructural Considerations. Construction and Building Materials, 24, 20112021. https://doi.org/10.1016/j.conbuildmat.2010.03.011

[48] Onitsuka, K. and Junan, S.H.E.N. (1998) Evaluation of Lime-Treated Ariake Clay with Fly Ash as Road Materials. Journal of Pavement Engineering, 3, 157-164. https://doi.org/10.2208/journalpe.3.157

[49] Feng, T.W. (2002) Effects of Small Cement Content on Consolidation Behavior of a Lacustrine Clay. Geotechnical Testing Journal, 25, 53-60.

[50] Saride, S., Puppala, A.J. and Chikyala, S.R. (2013) Swell-Shrink and Strength Behaviors of Lime and Cement Stabilized Expansive Organic Clays. Applied Clay Science, 85, 39-45. https://doi.org/10.1016/j.clay.2013.09.008

[51] Eades, J.L. and Grim, R.E. (1966) A Quick Test to Determine Lime Requirements for Lime Stabilization. Highway Research Record (139).

[52] Keller, W.D. (1964) Processes of Origin and Alteration of Clay Minerals. Soil Clay Mineralogy, 3-76.

[53] Hassan, M. (2009) Engineering Characterisitics of Cement Stabilized Soft Finnish Clay-A Laboratory Study. Licentiate's Thesis, Helsinki University of Technology, Helsinki.

[54] Wang, D., Abriak, N.E., Zentar, R. and Chen, W. (2013) Effect of Lime Treatment on Geotechnical Properties of Dunkirk Sediments in France. Road Materials and Pavement Design, 14, 485-503. https://doi.org/10.1080/14680629.2012.755935

[55] Rashid, A.S.A., Kalatehjari, R., Noor, N.M., Yaacob, H., Moayedi, H. and Sing, L.K. (2014) Relationship between Liquidity Index and Stabilized Strength of Local Subgrade Materials in a Tropical Area. Measurement, 55, 231-237. https://doi.org/10.1016/j.measurement.2014.05.018

[56] Ignat, R. (2015) Field and Laboratory Tests of Laterally Loaded Rows of Lime-Cement Columns. Doctoral Dissertation, KTH Royal Institute of Technology, Stockholm.

[57] Wang, D., Abriak, N.E. and Zentar, R. (2013) Strength and Deformation Properties of Dunkirk Marine Sediments Solidified with Cement, Lime and Fly Ash. Engineering Geology, 166, 90-99. https://doi.org/10.1016/j.enggeo.2013.09.007

\section{Submit or recommend next manuscript to SCIRP and we will provide best service for you:}

Accepting pre-submission inquiries through Email, Facebook, LinkedIn, Twitter, etc.

A wide selection of journals (inclusive of 9 subjects, more than 200 journals)

Providing 24-hour high-quality service

User-friendly online submission system

Fair and swift peer-review system

Efficient typesetting and proofreading procedure

Display of the result of downloads and visits, as well as the number of cited articles

Maximum dissemination of your research work

Submit your manuscript at: http://papersubmission.scirp.org/

Or contact eng@scirp.org 